\title{
Detrital zircon geochronology and evolution of the Nacimiento block late Mesozoic forearc basin, central California coast
}

\author{
Scott M. Johnston \\ Physics Department, California Polytechnic State University, San Luis Obispo, California 93407, USA \\ Andrew R.C. Kylander-Clark \\ Department of Earth Science, University of California, Santa Barbara, California 93106, USA
}

Alan D. Chapman

Geology Department, Macalester College, St. Paul, Minnesota 55105, USA

\begin{abstract}
Forearc basins are first-order products of convergent-margin tectonics, and their sedimentary deposits offer unique perspectives on coeval evolution of adjacent arcs and subduction complexes. New detrital zircon U-Pb geochronologic data from 23 sandstones and 11 individual conglomerate clasts sampled from forearc basin strata of the Nacimiento block, an enigmatic stretch of the Cordilleran forearc exposed along the central California coast, place constraints on models for forearc deformation during evolution of the archetypical Cordilleran Mesozoic margin. Deposition and provenance of the Nacimiento forearc developed in three stages: (1) Late JurassicValanginian deposition of lower Nacimiento forearc strata with zircon derived from the Jurassic-Early Cretaceous arc mixed with zircon recycled from NeoproterozoicPaleozoic and Mesozoic sedimentary sources typical of the continental interior; (2) erosion or depositional hiatus from ca. 135 to 110 Ma; and (3) Albian-Santonian deposition of upper Nacimiento forearc strata with zircon derived primarily from the Late Cretaceous arc, accompanied by Middle Jurassic zircon during the late AlbianCenomanian. These data are most consistent with sedimentary source terranes and a paleogeographic origin for the Nacimiento block south of the southern San Joaquin Basin in southern California or northernmost Mexico.

This interpreted paleogeographic and depositional history of the Nacimiento block has several implications for the tectonic evolution of the southern California Mesozoic margin. First, the Nacimiento forearc depositional history places new timing constraints on the Early Cretaceous unconformity found in forearc basin strata from the San Joaquin Valley to Baja California. This timing constraint suggests a model in which forearc basin accommodation space was controlled by accretionary
\end{abstract}


growth of the adjacent subduction complex, and where tectonic events in the forearc and the arc were linked through sediment supply rather than through orogenic-scale wedge dynamics. Second, a paleogeographic origin for the Nacimiento forearc south of the southern San Joaquin Valley places new constraints on end-member models for the kinematic evolution of the Sur-Nacimiento fault. Although this new paleogeographic reconstruction cannot distinguish between sinistral strike-slip and thrust models, it requires revision of existing sinistral-slip models for the Sur-Nacimiento fault, and it highlights unresolved problems with the thrust model.

\section{INTRODUCTION}

Subduction complexes, forearc basins, and magmatic arcs form together at convergent margins, and the coeval formation of this assemblage characterizes first-order tectonic processes controlling the growth of continental crust in arcs (Kelemen, 1995; Rudnick, 1995) and subsequent return of this material to the mantle in subduction zones (Clift and Vannucchi, 2004; Scholl and von Huene, 2007). However, the non-steady-state, perhaps cyclical nature of convergent-margin processes (e.g., Ducea, 2001; DeCelles and Graham, 2015) is not fully understood and presumably reflects the internal dynamics of the evolving orogenic wedge (DeCelles et al., 2009), and/or forces external to the orogen associated with variations in plate rates, slab dip, and collisions with oceanic highlands (Moxon and Graham, 1987; Jacobson et al., 2011; Kortyna et al., 2013; Sharman et al., 2015). Forearc basins are situated between subduction complexes and arcs, and the growth, architecture, provenance, and deformation of forearc basin strata provide a unique record of orogenic events in adjacent segments of convergent margins (e.g., Dickinson and Seely, 1979; Ingersoll, 1982, 1983; Dickinson, 1995; DeGraaffSurpless et al., 2002; Williams and Graham, 2013; Noda, 2016). Still, the mechanisms and rates by which forearc deposition and deformation respond to events within the convergent-margin system have not been fully characterized. For example, in the archetypical northern California Mesozoic forearc basin, midCretaceous changes in provenance are presumably related to tectono-magmatic reorganization of source terranes (Ingersoll, 1983), although these petrofacies changes have also been temporally linked to a switch from a nonaccretionary to accretionary regime in the forearc wedge (Dumitru et al., 2010). Farther south in the San Joaquin Valley and in Baja California, similar petrofacies changes coincide with the end of a regionally developed unconformity that has been temporally linked to the onset of arc contraction (Busby et al., 1998) and/or voluminous Late Cretaceous magmatism (Kimbrough et al., 2001). Also within the California Mesozoic forearc, the collision with an oceanic highland has been temporally and geographically linked to the removal of a large segment of the forearc in southern California along the Sur-Nacimiento fault. However, recent kinematic models for the evolution of the Sur-Nacimiento fault vary widely, with different models suggesting sinistral strike-slip fault displacement associated with forearc lateral escape (Dickinson, 1983; Jacobson et al.,
2011) or thrust displacement associated with forearc contraction (Hall, 1991; Hall and Saleeby, 2013).

Resolution of the processes that drove these changes to the style of forearc deposition and deformation requires constraints on the timing and nature of provenance shifts within the forearc that can be integrated with the evolving paleogeography of the entire convergent-margin system. As such, detrital zircon geochronology, which provides stratigraphic age control coupled to provenance data, permits investigation of these links between the forearc basin and regional tectonics (e.g., DeGraaff-Surpless et al., 2002; Jacobson et al., 2011; Hessler and Fildani, 2015). We present sandstone petrography data coupled with U-Pb zircon geochronology from sandstone and conglomerate clasts sampled from Upper Jurassic-Upper Cretaceous Nacimiento block forearc basin strata exposed along the central California coast. Our data reveal a Tithonian-Valanginian forearc provenance consisting of mixed North American continental and arc source terranes, a Barremian-Aptian unconformity, and an Albian-Santonian forearc provenance dominated by arc and forearc sources that progressively shifted eastward with the locus of active magmatism in the Late Cretaceous arc. This provenance evolution is consistent with a paleogeographic origin for the Nacimiento block in southern California south of the southern San Joaquin Valley or in northern Baja California. This interpretation has implications for the generation of accommodation space in forearc basins with respect to the dynamics of adjacent belts within a convergentmargin assemblage, and for kinematic models describing forearc deformation associated with the Sur-Nacimiento fault.

\section{GEOLOGIC BACKGROUND}

\section{Evolution of North American Mesozoic Convergent-Margin Assemblage}

The North American Cordillera includes Mesozoic arcs, forearc basins, and subduction complexes that stretch along the western margin of North America (Fig. 1). The earliest evidence for convergence is found in the Sierra Nevada-Mojave-Peninsular Ranges arcs, where magmatism had initiated by the latest Permian-Triassic. This was subsequently punctuated by highflux magmatic events in the Middle Jurassic and Late Cretaceous that were separated by relatively low-flux magmatic lulls (Ducea, 2001). Farther west, the geometry of the forearc was not fully 
established until after Middle Jurassic initiation of high-pressure metamorphism in the Franciscan subduction complex beneath the Coast Range ophiolite (Anczkiewicz et al., 2004; Wakabayashi and Dumitru, 2007; Ukar et al., 2012; Wakabayashi, 2015). The Franciscan subduction complex evolved from a forearc wedge characterized by relatively slow or nonexistent growth in the latest Jurassic-Early Cretaceous to a rapidly growing forearc wedge that was characterized by lateral expansion and extensional exhumation of subcreted material (Platt, 1986; Busby et al., 1998). In northern California, this accelerated growth of the subduction complex corresponded to a shift from a nonaccretionary regime characterized by subduction of trench material to an accretionary regime marked by frontal accretion of trench material at ca.
$123 \mathrm{Ma}$ (Dumitru et al., 2010, 2015). Similar increases in frontal accretion rates are observed within the Late Cretaceous forearc wedge in southern California (Grove et al., 2008). The onset of Laramide flat-slab subduction at ca. 90-75 Ma coincided with the gradual reduction and ultimate cessation of arc magmatism. In the subduction complex, the onset of Laramide subduction was marked by a reduction in the rate of forearc wedge accretion in northern California (Dumitru et al., 2015), and underplating of trench material beneath the Late Cretaceous arc in southern California (Grove et al., 2003; Saleeby, 2003).

Forearc basin strata were deposited on ophiolite basement along the length of the convergent margin from northern California to Baja California between the arc and its associated subduction

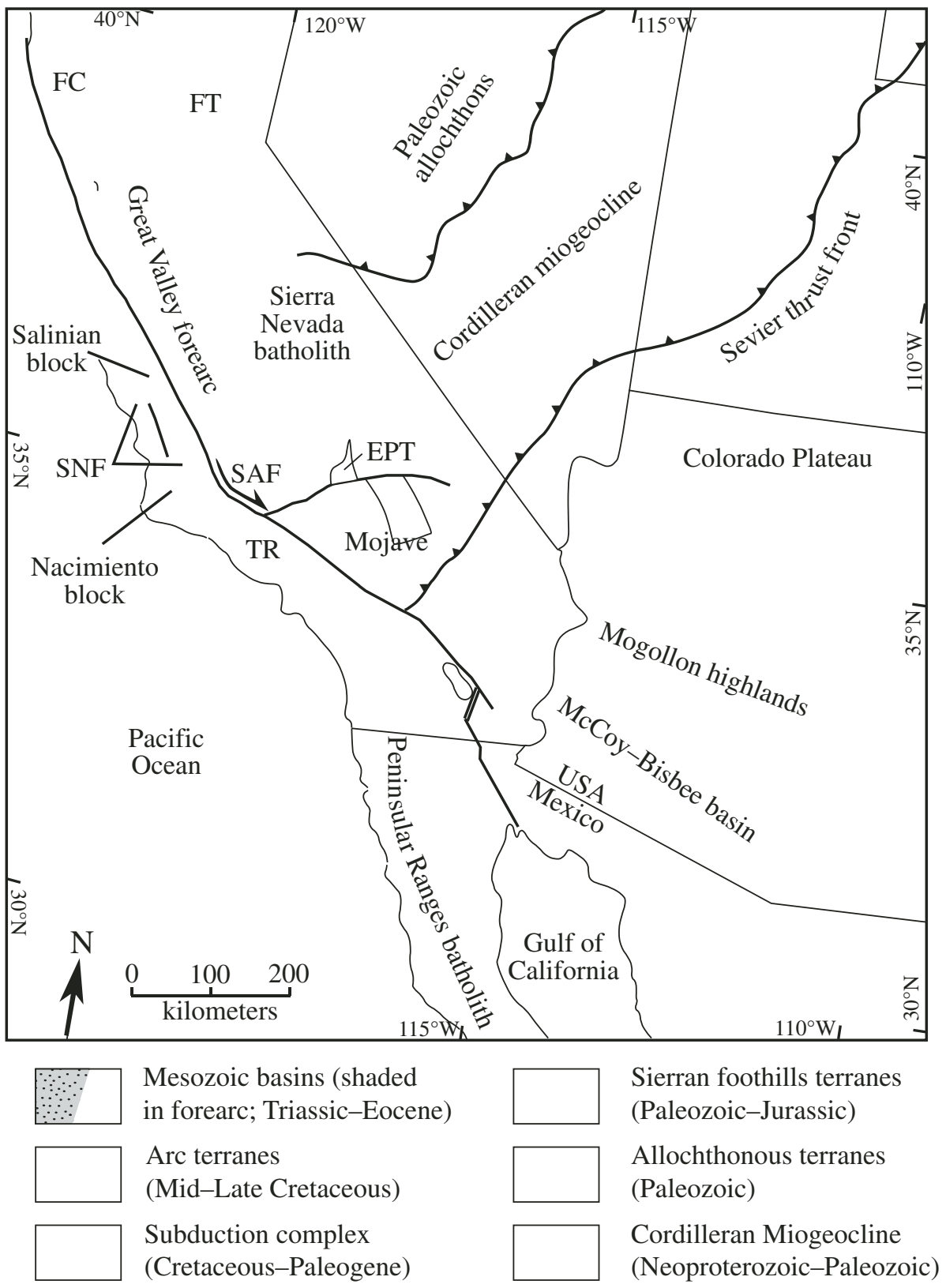

Figure 1. Regional geology of North American Cordillera (modified from Sharman et al., 2015, and references therein). EPT-El Paso terrane; FC-Franciscan Complex; FT-Foothills terrane; SAF-San Andreas fault; SNF-Sur-Nacimiento fault; TRTransverse Ranges. 
zone (Ingersoll, 1982; Barnes, 1984). Along-strike, forearc strata show similar depositional histories, including the timing of initial basin sedimentation in the latest Jurassic-Early Cretaceous (Ingersoll, 1982; Barnes, 1984; Surpless et al., 2006; Kimbrough et al., 2014), and rapid accumulation of Upper Cretaceous strata with particularly high accumulation rates in the San Joaquin Valley and Baja California during the Cenomanian (Moxon and Graham, 1987; Kimbrough et al., 2001). Sandstone petrography along the length of the forearc defines similar petrofacies that vary with time within the forearc strata: Lower Cretaceous lithic-rich sandstone is increasingly dominated by lithic volcanic clasts in the late Early Cretaceous to early Late Cretaceous, and these strata are overlain by more arkosic sandstone through the Late Cretaceous (Ingersoll, 1983; Barnes, 1984). These time-transgressive sandstone petrofacies are thought to represent progressive unroofing of adjacent arc source terranes (Ingersoll, 1983; Barnes, 1984).

Despite these similarities, northern and southern stretches of the forearc can be differentiated by significant variations in depositional history and provenance. With respect to depositional history, the nearly continuous record of sedimentation in the northern California western forearc basin contrasts sharply with a regionally developed unconformity in the Early Cretaceous observed in more eastern portions of the forearc basin exposed from the San Joaquin Valley to Baja California (e.g., Moxon, 1988; Busby et al., 1998). Similarly, along-strike stretches of the forearc basin display variations in Late Cretaceous provenance as recorded by detrital zircon and geochemical studies, and these can be attributed to corresponding along-strike variations in the geometry and geochemistry of Mesozoic arcs (e.g., Sharman et al., 2015; Surpless, 2015). Mudstone geochemistry from Sacramento Valley forearc basin strata suggests a relatively consistent arc source throughout the Early to Late Cretaceous, in contrast to San Joaquin Valley forearc mudstone units, which document a shift from primitive mafic source terranes in the late Early Cretaceous to evolved felsic sources in the Late Cretaceous (Surpless, 2015). Detrital zircon age spectra from Lower Cretaceous and Cenomanian sandstone are dominated by arc zircon with age peaks of ca. 160-140 Ma in the Sacramento Valley, ca. 120 Ma in the northern San Joaquin Valley, and ca. $160 \mathrm{Ma}$ in the southern San Joaquin Valley. Coniacian-Campanian strata from both the Sacramento and San Joaquin Valleys yield Late Cretaceous arc zircon younger than 120 Ma mixed with a roughly equal component of Jurassic and Early Cretaceous arc zircon (DeGraaffSurpless et al., 2002; Martin and Clemens-Knott, 2015). In contrast, south of the San Joaquin Valley, Cenomanian-Campanian sandstone is dominated by Late Cretaceous arc zircon younger than $120 \mathrm{Ma}$, with only rare Early Cretaceous and Jurassic arc zircon (Jacobson et al., 2011; Sharman et al., 2015).

\section{Mesozoic Rocks of the Central California Coast and the Sur-Nacimiento Fault}

The Salinian and Nacimiento blocks (Figs. 1 and 2) represent parts of the Mesozoic convergent margin that were trans- ported northwestward, as one amalgamated block, from southern California to the central California coast via Oligocene and younger dextral slip on the San Andreas fault (e.g., Hill and Dibblee, 1953; Atwater, 1989; Sharman et al., 2013). Directly to the southwest of the San Andreas fault, the Salinian block consists of Late Cretaceous arc plutonic rocks and high-grade metasedimentary rocks that have been correlated with central and eastern parts of the Cordilleran Mesozoic arc (e.g., Kistler and Peterman, 1978; Ross, 1978; Mattinson, 1990; Kidder et al., 2003). Farther to the southwest and exposed along the coast, the Nacimiento block consists of a Late Cretaceous subduction complex structurally below fragments of Jurassic ophiolitic basement overlain by Upper Jurassic-Campanian forearc basin strata (e.g., Page, 1970; Vedder et al., 1983; Dickinson et al., 2005; Chapman et al., 2016). Nacimiento block forearc basin strata are divided into lower and upper sections, although subtle variations have been noted along the length of the Nacimiento block (Fig. 2). The lower section (mapped as the Toro Formation in the northern and central Nacimiento block and the Espada Formation farther south) is characterized by Late Jurassic to Barremian, and possibly Albian, turbidite mudstone, interlayered lithic-rich sandstone, and rare conglomerate lenses (Dibblee, 1966; Hart, 1977; McLean et al., 1977; Seiders, 1982; Vedder et al., 1983). Sandstone petrography from the Toro Formation indicated an immature arc source (Gilbert and Dickinson, 1970; Seiders, 1983), while generally north-directed paleocurrent indicators together with northwarddecreasing concentrations of quartzite-clast conglomerate are consistent with source terranes from a southern promontory in the Sierran arc or southern California (Seiders, 1983; Seiders and Blome, 1988). Stratigraphically higher forearc basin strata (mapped as Atascadero Formation in the central Nacimiento block and as unnamed Cretaceous sandstone and shale in the San Rafael Range) are characterized by increasingly arkosic, Cenomanian-Campanian turbiditic sandstone and mudstone, massive sandstone, and conglomerate that yield temporally variable north- and south-directed paleocurrent indicators (Dibblee, 1966; Gilbert and Dickinson, 1970; Hart, 1977; McLean et al., 1977; Hall, 1981; Seiders, 1982; Vedder et al., 1983). Stratigraphic relationships between the Toro and Atascadero Formations in the central Nacimiento block are not preserved, and it cannot be assumed that they were originally part of the same section (Hart, 1977; Seiders, 1982). Farther south in the San Rafael Range, the section is apparently more complete, where Albian mudstone of the Espada Formation is overlain by thick Cenomanian conglomerate at the base of the Upper Cretaceous section (McLean et al., 1977; Vedder et al., 1983). Abundant mafic and ultramafic cobbles within this Cenomanian conglomerate have been used to argue for a mafic source terrane similar to oceanic crust exposed in the nearby Jurassic Point Sal ophiolite (McLean et al., 1977). However, abundant K-feldspar in sandstone and quartzite-poor, siliceous, volcanic-rich conglomerate in the majority of Upper Cretaceous Nacimiento forearc strata is consistent with abundant Late Cretaceous zircon; both characteristics are interpreted to reflect source terranes increasingly dominated by the gradually 


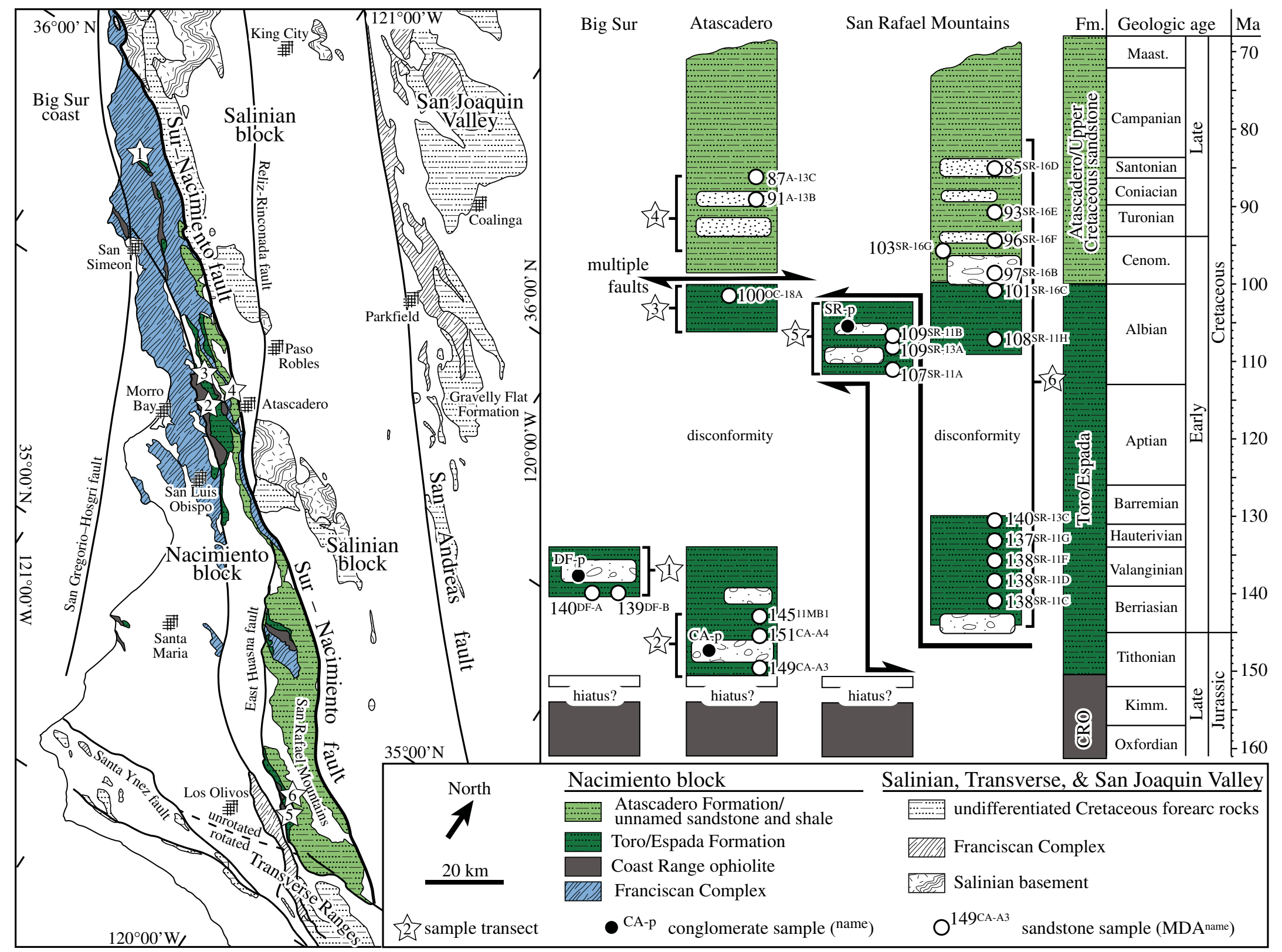

Figure 2. Geologic map of central California coast and Nacimiento forearc stratigraphy illustrating sample locations and their maximum depositional ages. Starred numbers on map refer to sampled sections indicated in stratigraphic columns. Maximum depositional ages adjacent to samples in stratigraphic columns are expressed in Ma. Map is modified from Chapman et al. (2016, and references therein); Nacimiento block-Transverse Ranges contact is from Onderdonk (2005). Maast.—Maastrichtian; Cenom.Cenomainian; Kimm.—Kimmeridgian; CRO—Coast Range ophiolite. 
unroofing Cretaceous arc (Hart, 1977; Vedder et al., 1983; Seiders and Blome, 1988; Jacobson et al., 2011).

In contrast to the northern California late Mesozoic margin, the convergent-margin assemblage southwest of the San Andreas fault is dissected by the Sur-Nacimiento fault, which juxtaposes the Salinian and Nacimiento blocks (Fig. 2). Based on the emplacement of Salinian arc crust against the Nacimiento forearc, and the removal of the majority of the western arc and inner forearc basin, a minimum offset of $150 \mathrm{~km}$ on the SurNacimiento fault is required (e.g., Page, 1970). Crosscutting relationships and stratigraphic cover constrain displacement on the Sur-Nacimiento fault to between ca. 76 and 62.5-56 Ma (Jacobson et al., 2011, and references therein). Subsequent deformation and reactivation of the Sur-Nacimiento fault have resulted in conflicting interpretations of its original slip sense (e.g., Page, 1970), and contractional (Page, 1970; Hall, 1991), dextral (McWilliams and Howell, 1982; Page, 1982), sinistral (Dickinson, 1983; Seiders, 1983; Jacobson et al., 2011), and extensional (Chapman et al., 2016) models for its evolution have been proposed.

\section{RESULTS}

\section{Zircon Geochronology}

Zircon U-Pb geochronology was performed on sandstone samples and conglomerate clasts from Nacimiento block forearc strata to define maximum depositional ages and provenance characteristics throughout its evolution. Zircon from each sample was isolated using standard rock-crushing, mineral-density, and magnetic-separation techniques. Individual zircon grains selected randomly from each sample were measured for $\mathrm{U}-\mathrm{Th}-\mathrm{Pb}$ isotopes by laser ablation-multicollector-inductively coupled plasmamass spectrometry (MC-ICP-MS) at the University of California, Santa Barbara (UCSB), following procedures of Kylander-Clark et al. (2013), with the exception of sample 11MB1, which was analyzed at the University of Arizona LaserChron Center following procedures of Gehrels et al. (2009). Reported isotope ratios were corrected against primary zircon standard 91500 (1065 Ma; Wiedenbeck et al., 1995) using the Iolite software package (Paton et al., 2010) and were not corrected for common Pb. Uncertainties on isotope ratios (reported at $2 \sigma$ ) were calculated by adding analytical uncertainty from unknowns to an additional $2 \%$ systematic uncertainty associated with the long-term reproducibility of secondary standards at the UCSB facility. "Best" ages for each analysis were determined by assigning the ${ }^{206} \mathrm{~Pb} /{ }^{238} \mathrm{U}$ age for grains younger than $900 \mathrm{Ma}$ or the ${ }^{207} \mathrm{~Pb} /{ }^{206} \mathrm{~Pb}$ age for grains older than $900 \mathrm{Ma}$. Analyses with $>10 \% 2 \sigma$ uncertainty on the best age, or that displayed $>10 \%$ discordance or $5 \%$ reverse discordance between ${ }^{206} \mathrm{~Pb} /{ }^{238} \mathrm{U}$ and ${ }^{207} \mathrm{~Pb} /{ }^{235} \mathrm{U}$ ages were identified and not considered in further analyses. In total, 76 out of 2028 total analyses from sandstone samples were omitted due to high uncertainty or discordance; 5 out of 552 total analyses were omitted from conglomerate clast samples. Maximum depositional ages for sandstone samples were determined by calculating the
${ }^{206} \mathrm{~Pb} /{ }^{238} \mathrm{U}$ weighted average age of the youngest statistically distinct single age population defined by three or more grains (e.g., Dickinson and Gehrels, 2009b); identification of statistically distinct young age populations defined by appropriate mean square of weighted deviates (MSWD) values was guided by the "Unmix ages" subroutine available in Isoplot (Ludwig, 2003). Sample locations, U-Pb isotopic results, and analyses used to determine maximum depositional ages are available in the Data Repository material (Tables DR1 and DR2). ${ }^{1}$

\section{Sandstone Detrital Zircon Geochronology}

We collected 23 samples of Upper Jurassic-Lower Cretaceous to Upper Cretaceous sandstone from the northern, central, and southern parts of the Nacimiento block to assess potential spatial and temporal provenance variability within the Nacimiento forearc (Figs. 2 and 3). Two samples of Lower Cretaceous sandstone were collected from the northern part of the Nacimiento block along the Big Sur coast, where exposures of forearc strata are limited to fault-bounded slivers of Coast Range ophiolite overlain by Toro Formation. In the central Nacimiento block at the latitude of Atascadero, we collected four sandstone samples from the Toro Formation (three from stratigraphically low positions, and one from a stratigraphically high position) and two stratigraphically high samples from the Atascadero Formation. Farther south, we collected 15 sandstone samples from an apparently continuous section of forearc strata including Lower Cretaceous Espada Formation that is overlain by unnamed Upper Cretaceous forearc mudstone and sandstone. Maximum depositional ages from the San Rafael Mountains section indicated that the lower part of the Espada Formation in the San Rafael Mountain section is out of order; this discontinuity indicates an unmapped fault (Fig. 2) that corresponds to a belt of discontinuously mapped lenses of serpentinite. To the east, and structurally above this fault, the Lower to Upper Cretaceous section is apparently intact.

Despite $>100 \mathrm{~km}$ of separation between northern and southern sampling sites, systematic variations in detrital zircon age distributions related to geographic location were not observed. However, samples from all three transects showed similarities when grouped by maximum depositional age, and these can be split into five age groups defined by strata with distinctive Cordilleran-aged (younger than $300 \mathrm{Ma}$ ) detrital zircon age spectra (Fig. 3). Three samples from the central Nacimiento block with Tithonian detrital zircon maximum depositional ages displayed a bimodal Jurassic age distribution with maxima at 150 and $163-171 \mathrm{Ma}$, separated by a minimum at $157 \mathrm{Ma}$; rare Triassic grains and a small Late Permian population that peaks

${ }^{1}$ GSA Data Repository Item 2018346-Multicollector-inductively coupled plasma-mass spectrometry zircon $\mathrm{U}-\mathrm{Pb}$ isotopic data for sandstone strata and conglomerate clasts, sandstone petrographic data, U-Pb concordia diagram for granitic clast SRp-3, reference list for Figures 6 and 8 -is available at www .geosociety.org/datarepository/2018/, or on request from editing@geosociety.org or Documents Secretary, GSA, P.O. Box 9140, Boulder, CO 80301-9140, USA. 


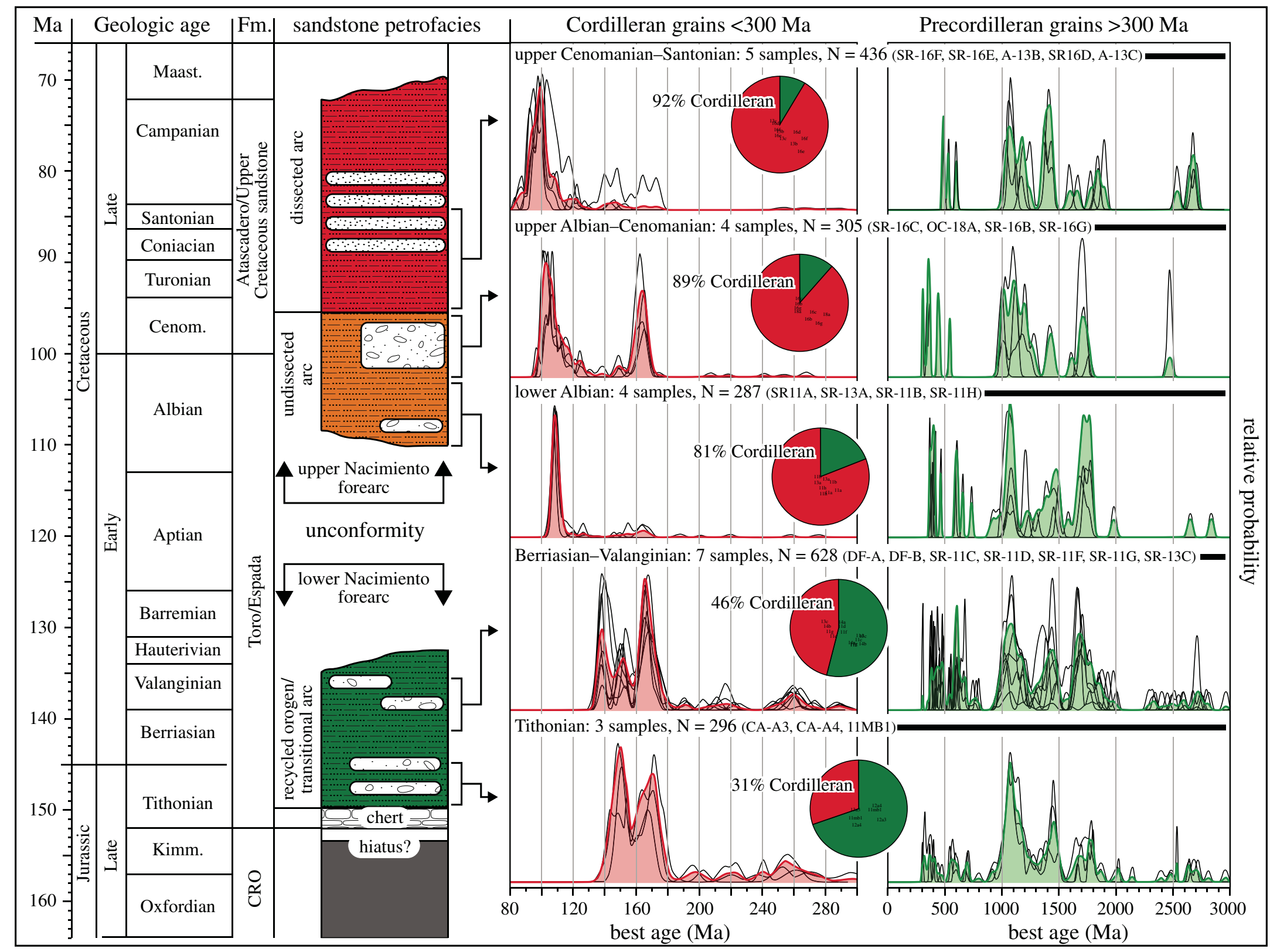

Figure 3. Detrital zircon geochronology results from Nacimiento forearc sandstone. Relative probability plots are filtered to include samples younger than 300 Ma and olde than $300 \mathrm{Ma}$ in Cordilleran and Precordilleran plots, respectively; plots display composite probability functions with colored curves and individual samples with thin dark lines. $\mathrm{N}$-number of analyses in composites from each depositional age group; pie plots indicate relative breakdown between Cordilleran and Precordilleran analyses from each composite. Maast.-Maastrichtian; Cenom.-Cenomainian; Kimm.-Kimmeridgian; CRO—Coast Range ophiolite. 
at $255 \mathrm{Ma}$ were also observed. Seven samples from the northern and southern transects with maximum depositional ages of 140-137 Ma displayed similar Jurassic and Permian detrital zircon age spectra, although this Berriasian-Valanginian sandstone included an additional detrital age maximum in the Early Cretaceous at $138 \mathrm{Ma}$.

Overlying these uppermost Jurassic-Lower Cretaceous strata, the Lower Albian strata are defined by four sandstone samples from the southern transect with maximum depositional ages of 109-107 Ma. In contrast to Tithonian-Valanginian sandstone, Lower Albian sandstone is dominated by Cretaceous zircon younger than $130 \mathrm{Ma}$, with a sharp age maximum at ca. 108 Ma. Early Cretaceous and Jurassic zircon grains with ages older than $130 \mathrm{Ma}$ in Lower Albian sandstone form minor maxima at 155 and 165 Ma and comprise only $15 \%$ of the Cordilleran-aged zircon population. Stratigraphically higher, three sandstone samples from the southern transect and one from the central transect yield younger maximum depositional ages of 103-97 Ma. These Upper Albian-Cenomanian samples are distinguished by bimodal age distributions, with a Cretaceous maximum at ca. $103 \mathrm{Ma}$ and abundant Jurassic zircon ages from 170 to $155 \mathrm{Ma}$, with a maximum at ca. $164 \mathrm{Ma}$, such that grains older than $130 \mathrm{Ma}$ comprise $40 \%$ of the Cordilleran-aged zircon population. The top of the Nacimiento block forearc section is defined by five samples from the central and southern transects that yield maximum depositional ages of 96-85 Ma and document continued forearc deposition from the Cenomanian through the Santonian. These youngest five samples are dominated by Late Cretaceous zircon populations with maxima younger than $100 \mathrm{Ma}$, and they are similar to Lower Albian sandstone in that grains older than $130 \mathrm{Ma}$ are rare, comprising only $11 \%$ of the Cordilleran-aged zircon population. Although proportions of Jurassic grains vary widely among these three groups of sandstone with Albian and younger ages, their Cretaceous detrital zircon spectra are similar in that $130-112 \mathrm{Ma}$ zircon is rare, comprising only $12 \%, 25 \%$, and $9 \%$ of the zircon population younger than $130 \mathrm{Ma}$ in Lower Albian, Upper Albian-Cenomanian, and Cenomanian-Santonian sandstone, respectively.

The five different Nacimiento block sandstone age groups are also differentiated by the component of Precordilleran zircon older than $300 \mathrm{Ma}$, which decreases dramatically in progressively younger sandstone groups. This variation initiated in the Early Cretaceous, as illustrated by a decrease from $69 \%$ to $54 \%$ between Tithonian and Berriasian-Valanginian sandstone, and it continued into the Late Cretaceous, with Precordilleran detritus composing $19 \%, 11 \%$, and $8 \%$ of the total zircon population in Lower Albian, Upper Albian-Cenomanian, and Upper Cenomanian-Santonian sandstone, respectively. Although the component of Precordilleran zircon is variable among sandstone age groups, Precordilleran zircon populations in all groups display similar age spectra with discrete age maxima at 480-360 Ma, 680-580 Ma, 1.2-1.0 Ga, ca. 1.4 Ga (1.45$1.42 \mathrm{Ga}$ grains are more abundant than $1.38 \mathrm{Ga}$ grains), 1.81.6 Ga, and Archean.

\section{Conglomerate Clast Zircon Geochronology}

Zircon geochronology was also performed on 11 sedimentary and igneous conglomerate clasts sampled from three conglomerate lenses from the Toro and Espada Formations (Figs. 2 and 3). Three light-gray to white quartzite clasts, $3-4 \mathrm{~cm}$ in diameter, were sampled from the stratigraphically lowest conglomerate in the center of the study area near the Cerro Alto campground and along strike from site 140 of Seiders and Blome (1988). The conglomerate at this locality contains abundant chert and quartzite pebbles, and it is Tithonian, based on fossil assemblages (Seiders, 1982) and maximum depositional ages of 151-149 Ma in adjacent sandstone (samples CA-3, CA-4). The three clasts yielded detrital zircon populations dominated by Precambrian ages (Fig. 4). Clast samples CA-p2 and CA-p4 displayed prominent age peaks at $1.2-1.0 \mathrm{Ga}$, ca. $1.4 \mathrm{Ga}(1.46 \mathrm{Ga}$ grains were more abundant than $1.37 \mathrm{Ga}$ grains), and fewer grains that yielded 1.81.6 Ga and Archean ages. Clast CA-p1 lacked 1.2-1.0 Ga and ca. 1.4 Ga populations and displayed a sharp age maximum at $1.8 \mathrm{Ga}$, accompanied by abundant Archean grains and two younger grains of 703 and 218 Ma.

Farther north along the Big Sur coast, four clasts were collected from conglomerate site 1 of Seiders (1983), who inferred a Valanginian depositional age that matches maximum depositional ages from adjacent sandstone of 140-139 Ma (samples DFA and DFB, this study). Conglomerate at this locality is dominated by chert clasts with less quartzite and rare sandstone cobbles up to $10 \mathrm{~cm}$ in diameter. Four clastic sedimentary cobbles with different characteristics in hand samples yielded diverse detrital zircon age spectra (Fig. 4). White quartzite sample DF-p7 displays a detrital age spectrum with age peaks at 1.2-1.0 Ga, ca. $1.4 \mathrm{Ga}$ (1.37 Ga grains are more abundant than $1.45 \mathrm{Ga}$ grains), and 1.8-1.6 Ga, and fewer Archean grains; two Mesozoic grains that overlap age maxima from adjacent sandstone samples are assumed to be contaminants from matrix sand that were not fully removed from the clast surface. Foliated white quartzite sample DF-p11 displays age peaks at $1.78 \mathrm{Ga}$ and $1.1 \mathrm{Ga}$, but it also includes Archean grains as well as two younger ages of 720 and 458 Ma. Sample DF-p6 is a gray quartzite with abundant Permian zircon that ranges in age from 280 to $248 \mathrm{Ma}$, with lesser peaks at ca. $460 \mathrm{Ma}, 1.2-1.0 \mathrm{Ga}$, ca. $1.4 \mathrm{Ga}$ (1.44-1.40 Ga grains more abundant than 1.32 Ga grains), and 1.8-1.6 Ga. Sample DF-p9 is a tan sandstone with muddy rip-up clasts up to $5 \mathrm{~mm}$ in length. This sandstone sample contains abundant zircon with 1.2-1.0 Ga ages, as well as lesser age peaks in the Archean, Paleoproterozoic, Neoproterozoic, and Phanerozoic, with ages as young as $222 \mathrm{Ma}$.

Conglomerate clasts from the San Rafael Mountains were sampled from a pebble-cobble conglomerate composed of quartzite, sandstone, chert, and granitic and volcanic clasts. The depositional age of this conglomerate is Albian, based on the presence of metavolcanic clasts similar to other upper Lower Cretaceous conglomerate in the Nacimiento block (Seiders and Blome, 1988), and maximum depositional ages of 109-107 Ma from three sandstone samples stratigraphically below this 


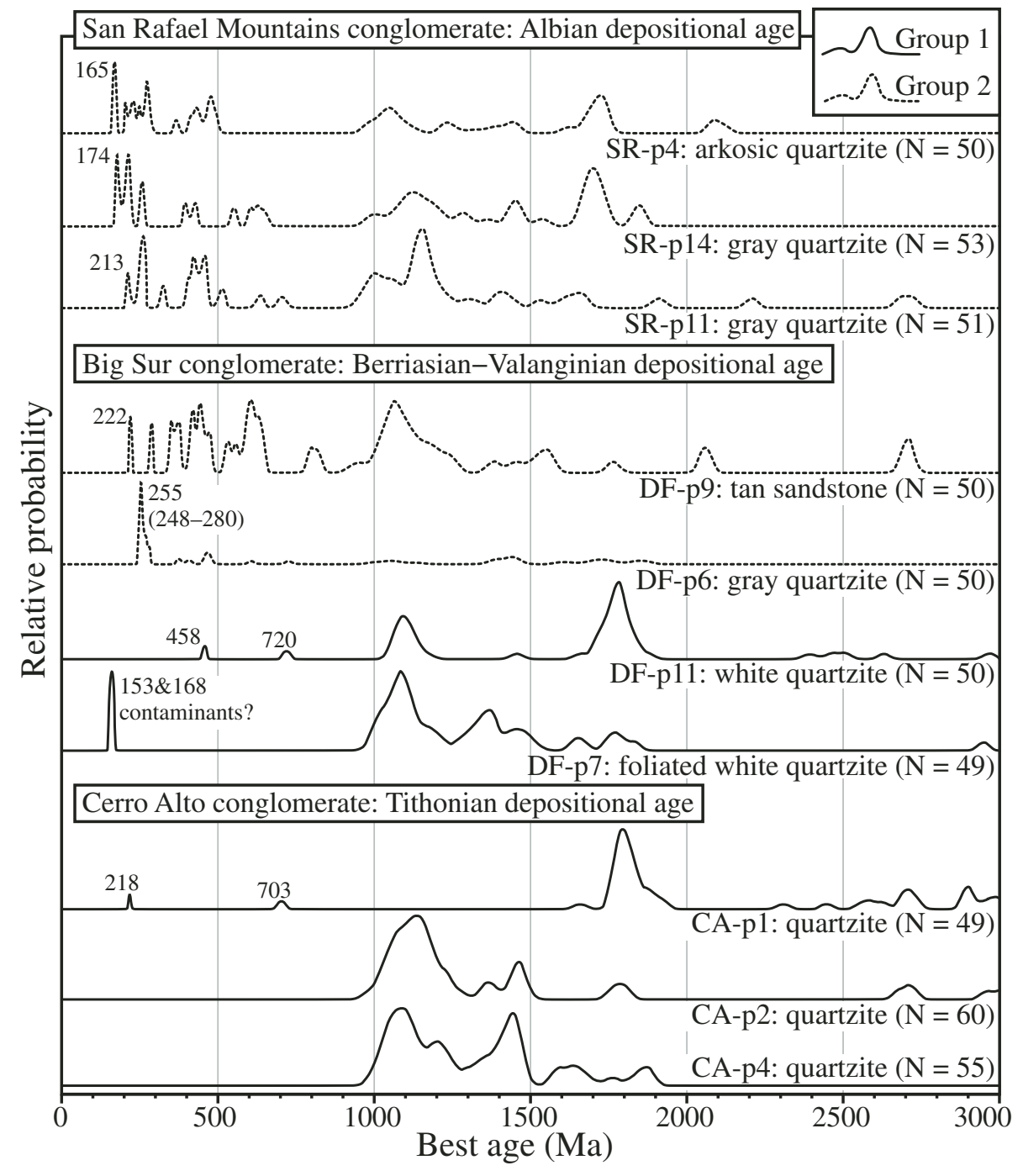

Figure 4. Detrital zircon geochronology results from sandstone and quartzite conglomerate clasts sampled from Albian, Berriasian-Valanginian, and Tithonian Nacimiento forearc conglomerate. outcrop. Three sandstone clasts sampled from this outcrop yielded zircon with Mesozoic ages (Fig. 4). Gray quartzite sample SR-p11 included Phanerozoic zircon as young as 213 Ma, abundant 1.2-1.0 Ga zircon, and minor Paleoproterozoic and Neoproterozoic zircon. Arkosic sandstone SR-p4 and gray quartzite SR-p14 contained Phanerozoic grains as young as the Jurassic (165 and $174 \mathrm{Ma}$, respectively), and roughly equivalently age peaks at $1.2-1.0 \mathrm{Ga}$, ca. $1.4 \mathrm{Ga}$ (1.44 Ga grains more abundant than $1.39 \mathrm{Ga}$ grains), and 1.8-1.6 Ga. One granitic clast from this locality (SR-p3) yielded a ${ }^{206} \mathrm{~Pb} /{ }^{238} \mathrm{U}$ weighted average age of $164.3 \pm 3.4 \mathrm{Ma}(2 \sigma)$ from 29 of 30 individual analyses (Fig. DR1 [see footnote 1]).

\section{Sandstone Petrography}

Petrographic analyses were completed on 22 sandstone samples from Nacimiento block forearc strata. Point counts of sandstone were made using the Gazzi-Dickinson method on standard thin sections that were stained to aid with the identification of
K-feldspar. Analyses of Qt (monocrystalline and polycrystalline quartz) + F (K-feldspar and plagioclase) + L (volcanic, sedimentary, and metamorphic lithic fragments) exceeded 200 counts in each sample. Other counted detrital components included phyllosilicates, pyroxene, epidote, zircon, and opaque phases, along with matrix calcite and undifferentiated matrix. Complete sandstone petrography results for each sample are available in the Data Repository material (Table DR3 [see footnote 1]).

Detrital modes display strong correlation with the maximum depositional ages presented above, and they define at least three distinct populations on a QtFL diagram (e.g., Dickinson et al., 1983) associated with Tithonian to Valanginian, Albian to Cenomanian, and Upper Cenomanian to Santonian age groups (Fig. 5). Tithonian to Valanginian samples are quartz-rich lithic sandstones that plot near the top of the transitional-arc provenance field, and they display plagioclase to total feldspar ratios $(\mathrm{P} / \mathrm{F})>0.75$ in 8 of 9 samples. Within these samples, older Tithonian samples from the base of the Toro Formation yielded more quartzite than chert and plotted near the boundary with the recycled-orogenic field, 


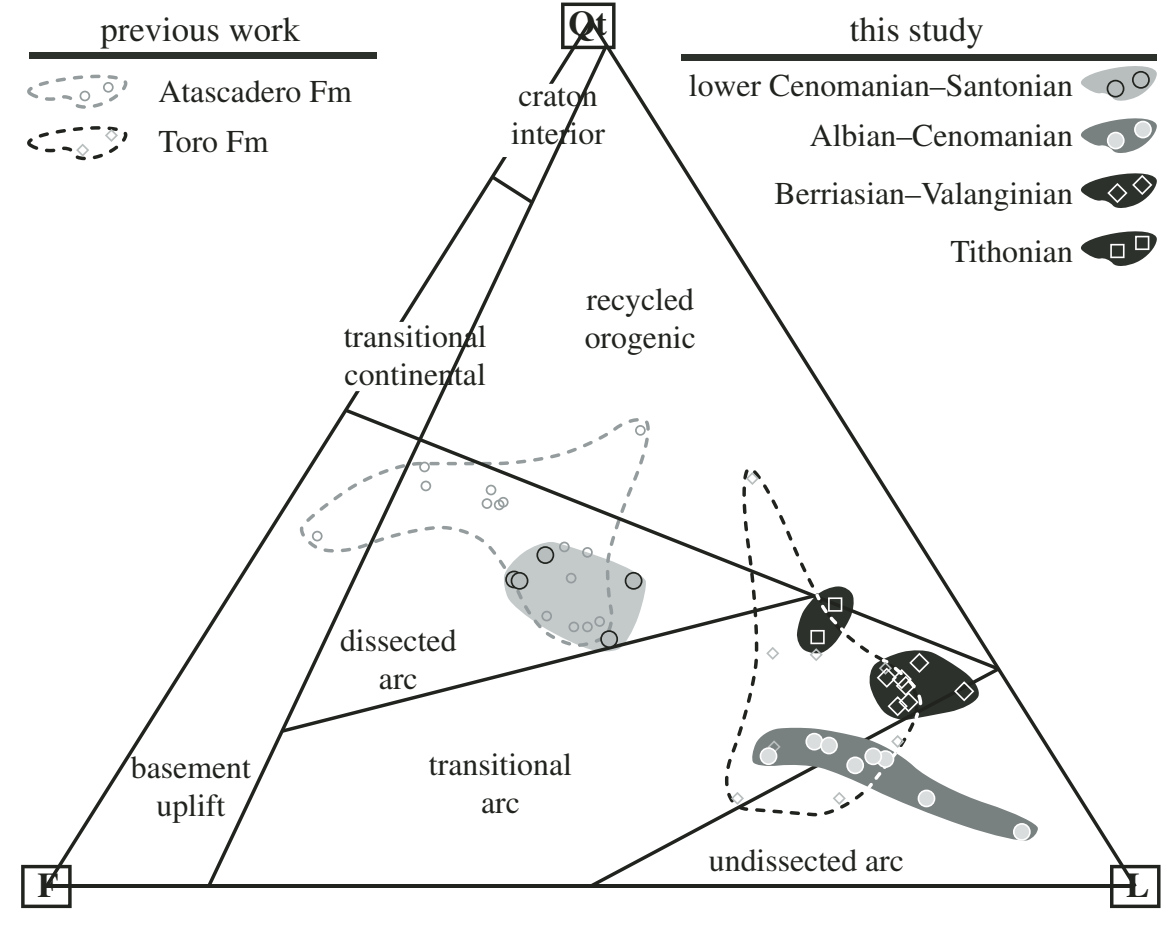

Figure 5. Sandstone detrital modes from Nacimiento forearc sandstone plotted on QtFL ternary diagram, where Qt (monocrystalline and polycrystalline quartz) $+\mathrm{F}$ (K-feldspar and plagioclase) + L (volcanic, sedimentary, and metamorphic lithic fragments). Tectonic provenance fields are after Dickinson et al. (1983). Previous results from Gilbert and Dickinson (1970) and Seiders (1983) are shown. whereas Valanginian samples had more lithic volcanic clasts, more chert than quartzite, and less feldspar. Albian through Cenomanian samples are quartz-poor lithic sandstones that plot across the boundary of transitional-arc and undissected-arc provenance fields (Fig. 5). Feldspar in these samples is dominantly plagioclase, and $\mathrm{P} / \mathrm{F}$ is $>0.9$ in all samples. Several samples within this group (SR-11H, SR-16C, SR-16G) contain distinct rounded and weathered volcanic grains that comprise $40 \%-60 \%$ of L. Upper Cenomanian through Santonian sandstone is more arkosic and plots in the dissected-arc provenance field (Fig. 5). These samples are characterized by abundant quartz, K-feldspar, and plagioclase, and they yield lower $\mathrm{P} / \mathrm{F}$ ratios of $0.45-0.68$.

\section{DISCUSSION}

\section{Nacimiento Block Forearc Stratigraphic Age Control}

The earliest documented terrigenous sedimentation in the Nacimiento forearc comes from the Toro Formation, where previous workers identified at least three localities yielding Tithonian Buchia piochii (Gilbert and Dickinson, 1970; Page, 1972; Hart, 1977). In the lower Great Valley Group of the Sacramento Valley, the Tithonian depositional ages based on fossil assemblages have been questioned based on the presence of Early Cretaceous detrital zircon in sandstone that also yields Tithonian fossils (Surpless et al., 2006). Six of 296 grains from three sandstone samples of Toro Formation analyzed in this study yielded Cretaceous ages younger than $145 \mathrm{Ma}$. However, the uncertainties of these analyses overlap with older grains, and maximum depositional ages of 151-145 Ma determined for the lowermost Toro
Formation support the Tithonian onset of deposition within the Nacimiento block forearc basin. Still, the Tithonian-Berriasian section is sparse or absent in other parts of the Nacimiento block, and deposition in the Nacimiento block forearc likely did not become widespread until the Early Cretaceous, as defined by the thick Berriasian-Valanginian section dated by both fossils and detrital zircon.

Following Tithonian-Valanginian deposition, the Nacimiento block forearc experienced either nondeposition or erosion until the latest Early Cretaceous. Vedder et al. (1983) cited unpublished fossil evidence suggesting forearc deposition continued through the Hauterivian or Barremian. However, zircon maximum depositional ages from the San Rafael Mountains document a gap in the depositional record from the Valanginian to the Albian, and maximum depositional ages from the central Nacimiento block suggest a similar gap from the Valanginian to the Cenomanian. This apparent gap within the depositional record is included wholly within lithic-rich turbidites previously assigned to the Jurassic-Lower Cretaceous Toro and Espada Formations (Dibblee, 1966; Gilbert and Dickinson, 1970; Hart, 1977; McLean et al., 1977; Seiders, 1982; Vedder et al., 1983). However, this depositional gap also coincides with notable provenance shifts in the petrographic and detrital zircon record (see following discussion), and for the purposes of this provenance and tectonic discussion, we redefine the "lower" versus "upper" nomenclature of the Nacimiento block stratigraphy. We assign the Tithonian-Valanginian Toro and Espada Formations to lower Nacimiento forearc strata, and the Albian and younger upper Toro/Espada Formations and the Atascadero Formation to upper Nacimiento forearc strata (Fig. 3). 


\section{Nacimiento Block Provenance and}

\section{Regional Paleogeography}

\section{Conglomerate Clast Provenance}

Sandstone and quartzite clasts in Nacimiento forearc conglomerate can be split into two groups and correlated with potential source strata based on their relative concentrations of zircon with Paleozoic and Neoproterozoic ages (Figs. 4 and 6). Group 1 clasts, with rare or nonexistent Paleozoic and Neoproterozoic zircon, are typically white quartzite, locally foliated, that displays age maxima at $1.2-1.0 \mathrm{Ga}$, ca. $1.4 \mathrm{Ga}$, and $1.8-1.6 \mathrm{Ga}$ and Archean intervals. In contrast, group 2 clasts are darker quartzite and sandstone that yield 700-300 Ma zircon, as well as grains as young as Permian, Triassic, or Jurassic, presumably derived from Cordilleran arcs. Comparison of detrital zircon spectra from Nacimiento clasts to composite spectra from potential source terranes suggests that group 1 clasts can be loosely correlated with Neoproterozoic-Lower Paleozoic shelf strata, which lack significant zircon younger than $900 \mathrm{Ma}$, and group 2 clasts can be most closely correlated with Triassic-Jurassic strata of the Colorado Plateau, arc flanks, and Cordilleran rifts (Fig. 6A). More detailed comparison of clasts to individual samples selected from within composite spectra displays even stronger correlations (Fig. 6B). For example, group 1 Nacimiento clasts with abundant Grenvillian zircon (1.2-1.0 Ga) display detrital zircon spectra similar to inner-shelf miogeoclinal strata in Death Valley (e.g., the Johnnie Formation; Schoenborn et al., 2012), and clasts dominated by ca. $1.8 \mathrm{Ga}$ zircon may be correlative to outer-shelf facies exposed in the White-Inyo Range (Chapman et al., 2015). Group 2 clasts with abundant Permian detritus resemble Triassic Chinle Formation southern feeder rivers (e.g., Dickinson and Gehrels, 2008). Group 2 clasts with zircon as young as Triassic may correlate with either the Triassic Chinle Formation or the Middle Jurassic Kayenta Formation (e.g., Dickinson and Gehrels, 2008, 2009a), and group 2 clasts with grains as young as Jurassic may correlate with Cordilleran rift strata (e.g., the basal McCoy Mountains Formation; Barth et al., 2004; Spencer et al., 2011). On the other hand, detrital zircon spectra in potential source strata are similar across broad regions of space and time, and these potential correlations are nonunique. As such, we interpret these conglomerate clast results cautiously, and loosely correlate group 1 clasts with shelf strata of the Neoproterozoic-Paleozoic Laurentian margin, and Triassic-Jurassic group 2 clasts with strata of the Colorado Plateau, arc flanks, and Cordilleran rifts.

Lower Nacimiento forearc conglomerate is dominated by group 1 clasts from Neoproterozoic-Lower Paleozoic source strata, although Berriasian-Valanginian conglomerate in Big Sur also includes group 2 clasts with Triassic minimum ages of probable Colorado Plateau origin. The occurrence of both of these clast types in the same outcrop requires source strata in close proximity or recycling from older conglomerate. Although Neoproterozoic-Paleozoic shelf strata are closely related over much of the continental interior, they crop out in a relatively narrow belt that trends along the Nevada-Utah border and into the Mojave Desert, southern California, Arizona, and northernmost Mexico. As such, we follow Seiders and Blome (1988) and suggest that the intersection of Neoproterozoic-Paleozoic shelf strata with Triassic strata of the Colorado Plateau and the Jurassic Cordilleran arc in the Mojave Desert, southern California, and northernmost Mexico represents the most likely source terrane for lower Nacimiento forearc conglomerate, as opposed to regions farther north, where Neoproterozoic-Paleozoic shelf strata were located in the retroarc, far from the forearc (Fig. 7A).

By the Albian, quartzite and sandstone clasts in upper Nacimiento forearc strata were relatively rare, and felsic volcanic clasts were abundant (Seiders and Blome, 1988); one granitic clast yielded an age of $164 \mathrm{Ma}$ (Fig. DR1 [see footnote 1]), which coincides with Middle Jurassic magmatism recorded in many places within Cordilleran arcs (e.g., Paterson and Ducea, 2015). Despite relatively small sample sizes, our conglomerate clast data suggest that quartzite and sandstone clasts that entered the forearc basin were sourced from group 2 Triassic and Jurassic strata, whereas group 1 Neoproterozoic-Paleozoic clasts were absent or rare. This observation suggests that Triassic-Jurassic strata from the Colorado Plateau and Cordilleran arc-flanks and/ or Cordilleran rifts represented the primary clastic sedimentary sources to upper Nacimiento forearc strata. The lack of group 1 Neoproterozoic-Paleozoic clasts also suggests that these older strata must have been either erosionally removed or covered by sediments within the source terrane, or that paleorivers flowing from the continental interior were blocked from the forearc by the maturing arc (Fig. 7C).

\section{Lower Nacimiento Forearc Sandstone Provenance}

All Tithonian-Valanginian lower Nacimiento forearc sandstone yields abundant Precordilleran zircon older than $300 \mathrm{Ma}$ with age maxima at 480-350 and 700-560 Ma, $1.2-1.0 \mathrm{Ga}$, ca. 1.4 Ga, and 1.8-1.6 Ga and Archean. Similar Precordilleran zircon age maxima are observed in Upper Jurassic-Lower Cretaceous forearc strata stretching the length of the Cordilleran margin from Baja California to the Blue Mountains and have been interpreted to indicate that this Precordilleran zircon signature was at least partially achieved through recycling of older Triassic-Jurassic strata of the Colorado Plateau (LaMaskin et al., 2011; Kimbrough et al., 2014). Likewise, the presence of group 2 Triassic sandstone clasts in Valanginian conglomerates of the Nacimiento block that yield detrital zircon age spectra that are broadly similar to those of Triassic strata of the Colorado Plateau indicates that at least some of the Precordilleran zircon in Nacimiento forearc sandstone could have been recycled therefrom. However, lower Nacimiento sandstone is distinguished from other Lower Cretaceous forearc strata by its scarcity of 700-300 Ma zircon (Fig. 8A). Whereas 700-300 Ma grains comprise $13 \%$ and $20 \%$ of Precordilleran zircon in Tithonian and Berriasian-Valanginian Nacimiento forearc sandstone, respectively, much higher proportions of 700-300 Ma zircon are found in Upper Jurassic-Lower Cretaceous forearc strata of the Blue Mountains (37\%; LaMaskin et al., 2011), the Sacramento Valley 


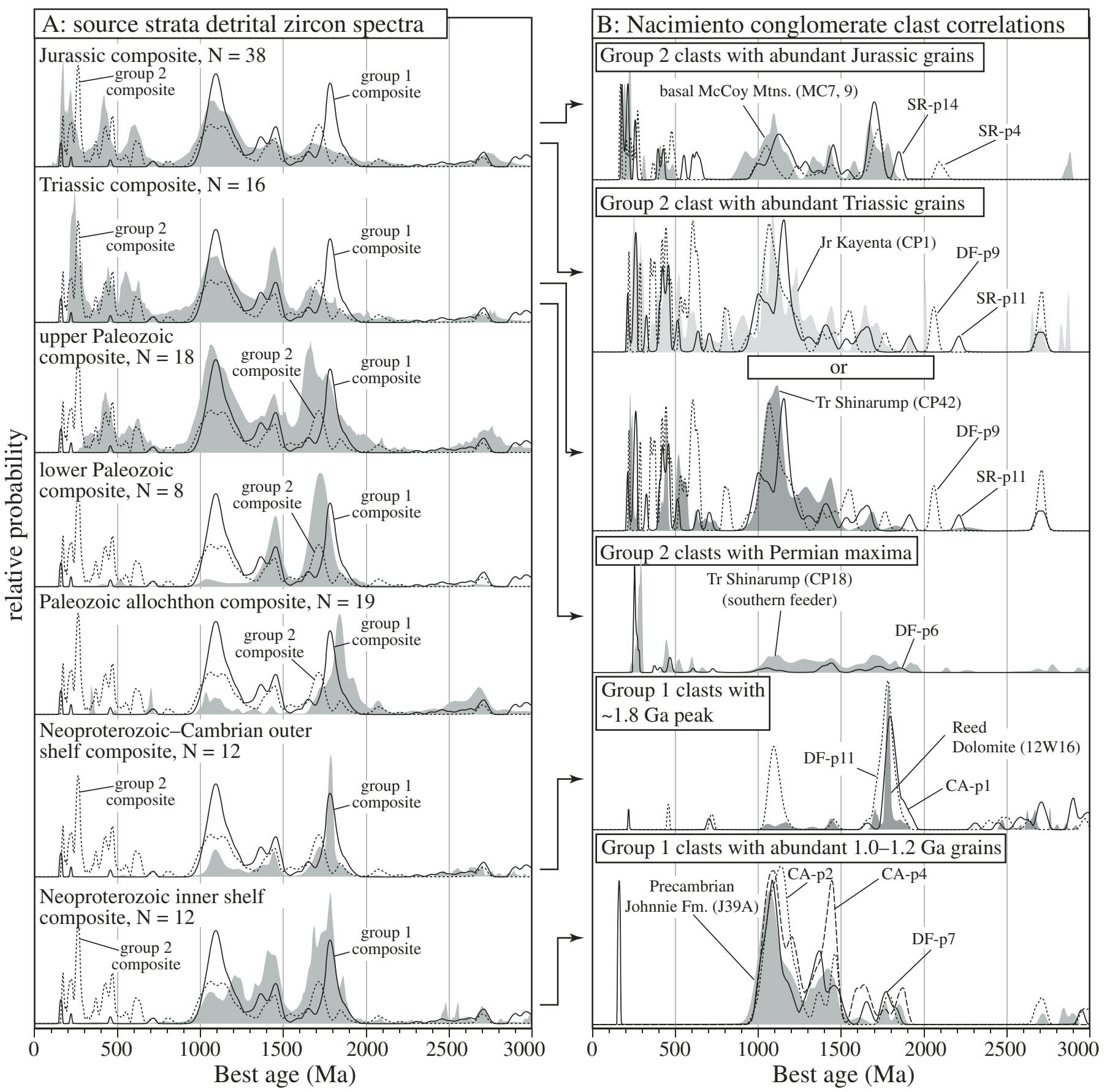

Figure 6. Comparisons of detrital zircon age spectra from Nacimiento forearc conglomerate clasts with spectra from potential source strata: (A) comparison of group 1 and group 2 composite clast spectra with composite terrane spectra, and (B) comparison of individual Nacimiento clasts with potential single-sample sources selected from composite terranes based on similar detrital zircon age spectra. Nacimiento clast spectra are indicated with thin black curves; source spectra are indicated by gray fields. For sample names and references for composite and individual source strata, see Appendix DR1 (text footnote 1). Jr-Jurassic; Tr-Triassic. 
North American source terranes

Triassic-Jurassic sedimentary rocks

Paleozoic allochthonous terranes

Neoproterozoic-Paleozoic shelf sediments

Cordilleran arc rocks

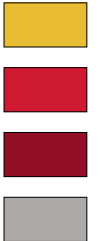

$<85 \mathrm{Ma}$

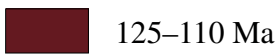

$100-85 \mathrm{Ma}$

$110-100 \mathrm{Ma}$

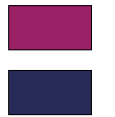

Jurassic-Early Cretaceous

undifferentiated metamorphic pendants

Forearc rocks

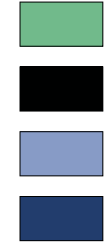

forearc basin sediments

Coast Range ophiolite

subduction complex

oceanic crust

Map symbols

thrust fault

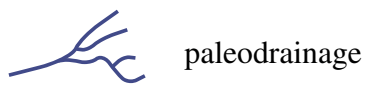

,$\quad$ Oligocene

future faults
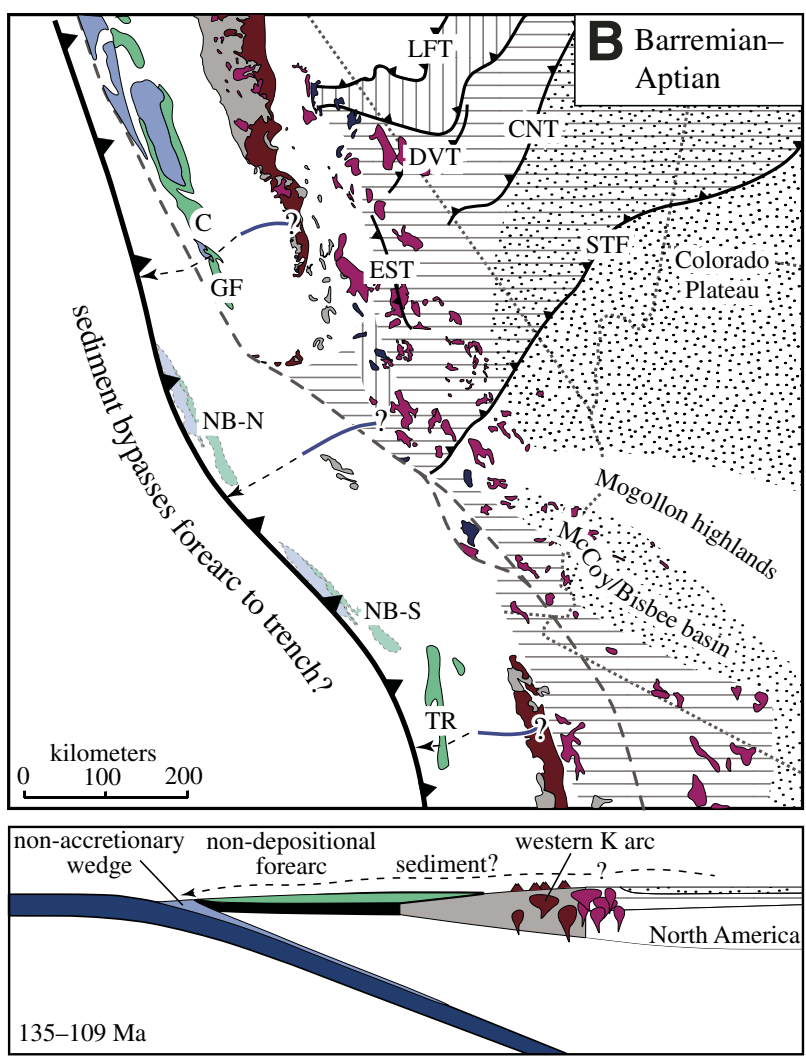
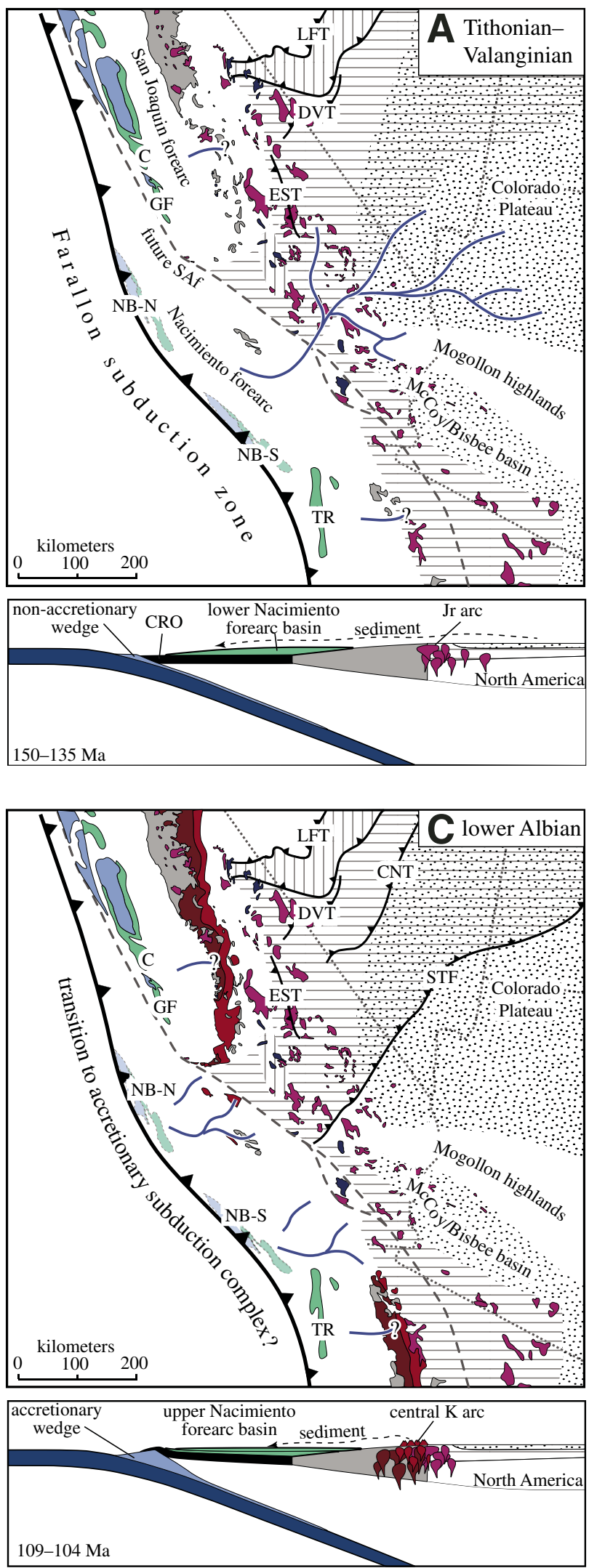

Figure 7 (Continued on following page). Maps and cross sections illustrating evolution of Cordilleran margin and forearc source terranes for southern California and northernmost Mexico. 

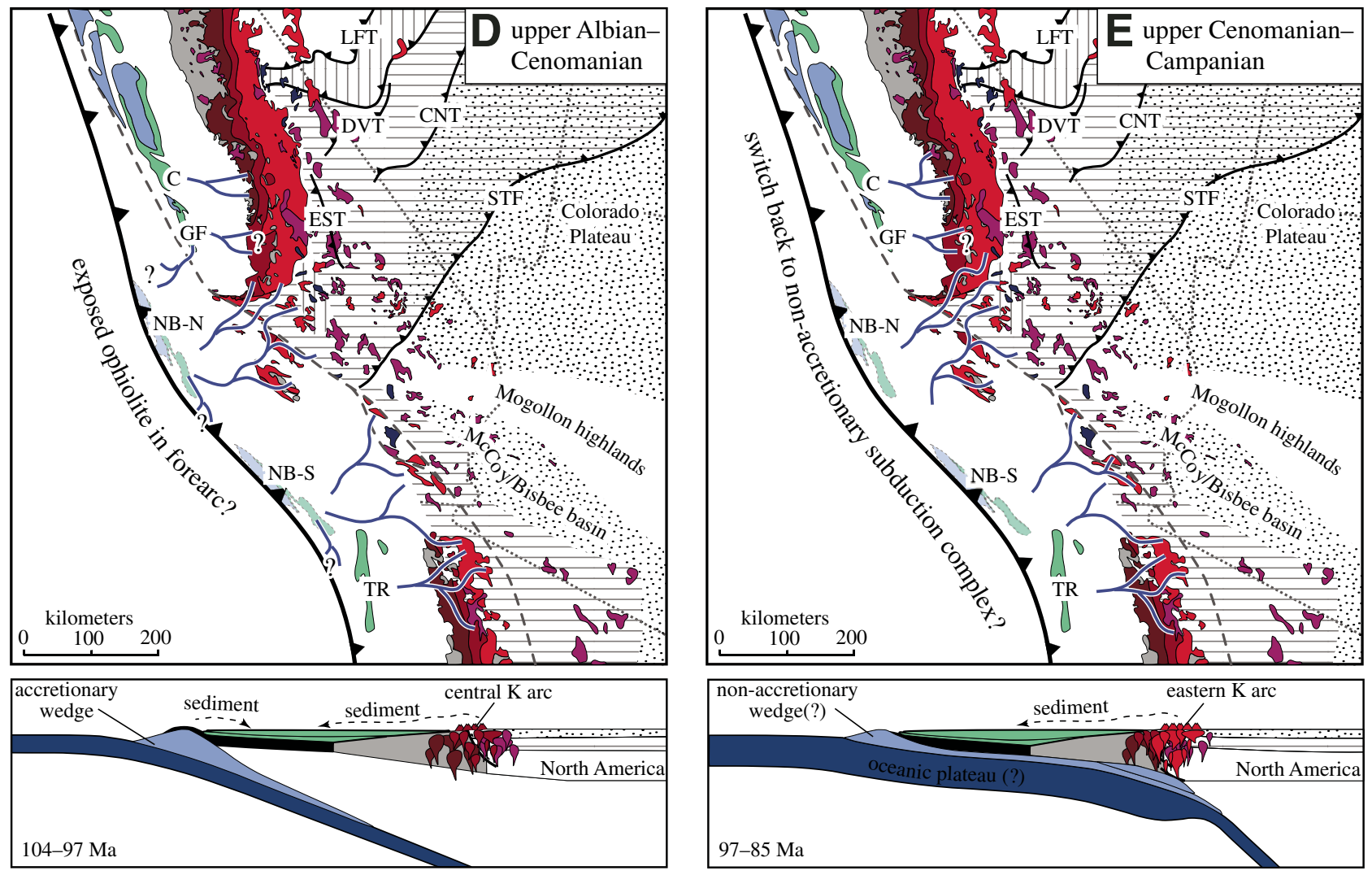

Figure 7 (Continued). Alternate northern (NB-N) and southern (NB-S) models for Nacimiento block and its forearc paleodrainages permitted by data in this paper are given south of the southern San Joaquin Valley. Schematic cross sections are drawn across convergent margin at latitude of reconstructed Nacimiento forearc in southern California. Pre-San Andreas fault reconstruction of the Salinian block in southern California is after Sharman et al. (2015). Generalized plutonic age maps within Sierra Nevada-Mojave-SalinianPeninsular Ranges composite batholith are after Ortega-Rivera (2003), Chapman et al. (2012), Premo et al. (2014), and Sharman et al. (2015). North American tectonic terranes and Cenomanian-Santonian forearc paleodrainages are after Sharman et al. (2015). Thrust-belt locations and timing are after DeCelles and Graham (2015). Extent of Colorado Plateau Mesozoic siliciclastic strata is after Dickinson and Gehrels (2010). C—Coalinga; CNT — central Nevada thrust belt; CRO—Coast Range ophiolite; DVT—Death Valley thrust belt; EST—east Sierra thrust system; GF_Gravelly Flat; Jr_Jurassic; K_Cretaceous; LFT_Luning-Fencemaker thrust belt; SAf—San Andreas fault; STF_-Sevier thrust front; TR — Transverse Ranges.

(42\%; DeGraaff-Surpless et al., 2002; Surpless et al., 2006), and the Peninsular Ranges (33\%; Kimbrough et al., 2014). Notably, 700-300 Ma zircon comprises only 12\% of Precordilleran zircon in Lower Cretaceous (?) forearc sandstone from the Gravelly Flat Formation of the southern San Joaquin Valley (Martin and Clemens-Knott, 2015), and 9\% in the Upper Jurassic-Lower Cretaceous McCoy Mountains Formation (Barth et al., 2004), and these units are thus broadly similar to lower Nacimiento forearc sandstone. This scarcity of 700-300 Ma detritus in lower Nacimiento sandstone may be due to provenance from source strata with detrital zircon spectra similar to group 2 Jurassic conglomerate clasts (Fig. 8B), although these clasts apparently did not arrive in abundance to the Nacimiento forearc until the Albian (e.g., Fig. 4). Alternatively, given the abundance of group 1 Neoproterozoic-Paleozoic quartzite clasts and group 2 Triassic clasts in lower Nacimiento forearc conglomerate (Fig. 4; Seiders, 1983; Seiders and Blome, 1988), we suggest that the scarcity of 700-300 Ma zircon in lower Nacimiento forearc sandstone indicates a mixture of zircon populations recycled from Triassic strata with abundant 700-300 Ma zircon and NeoproterozoicPaleozoic miogeoclinal strata with only rare 700-300 Ma zircon (Fig. 8B). We thus infer a source terrane for lower Nacimiento forearc sandstone in southern California, the Mojave Desert, Arizona, or northernmost Mexico, where Triassic strata and Neoproterozoic-Paleozoic strata are spatially most closely associated with the Jurassic Cordilleran arc (Fig. 7A).

Cordilleran detrital zircon with ages younger than $300 \mathrm{Ma}$ from lower Nacimiento forearc sandstone displays discrete age maxima in the Early Cretaceous (145-135 Ma), Late Jurassic (155-145 Ma), and Middle Jurassic (175-158 Ma), with rare Triassic zircon and a subordinate age maximum in the PermianEarly Triassic (275-245 Ma). Middle and Late Jurassic zircon age maxima in lower Nacimiento forearc sandstone at 166 and $151 \mathrm{Ma}$ could have been derived from diverse Cordilleran arc 

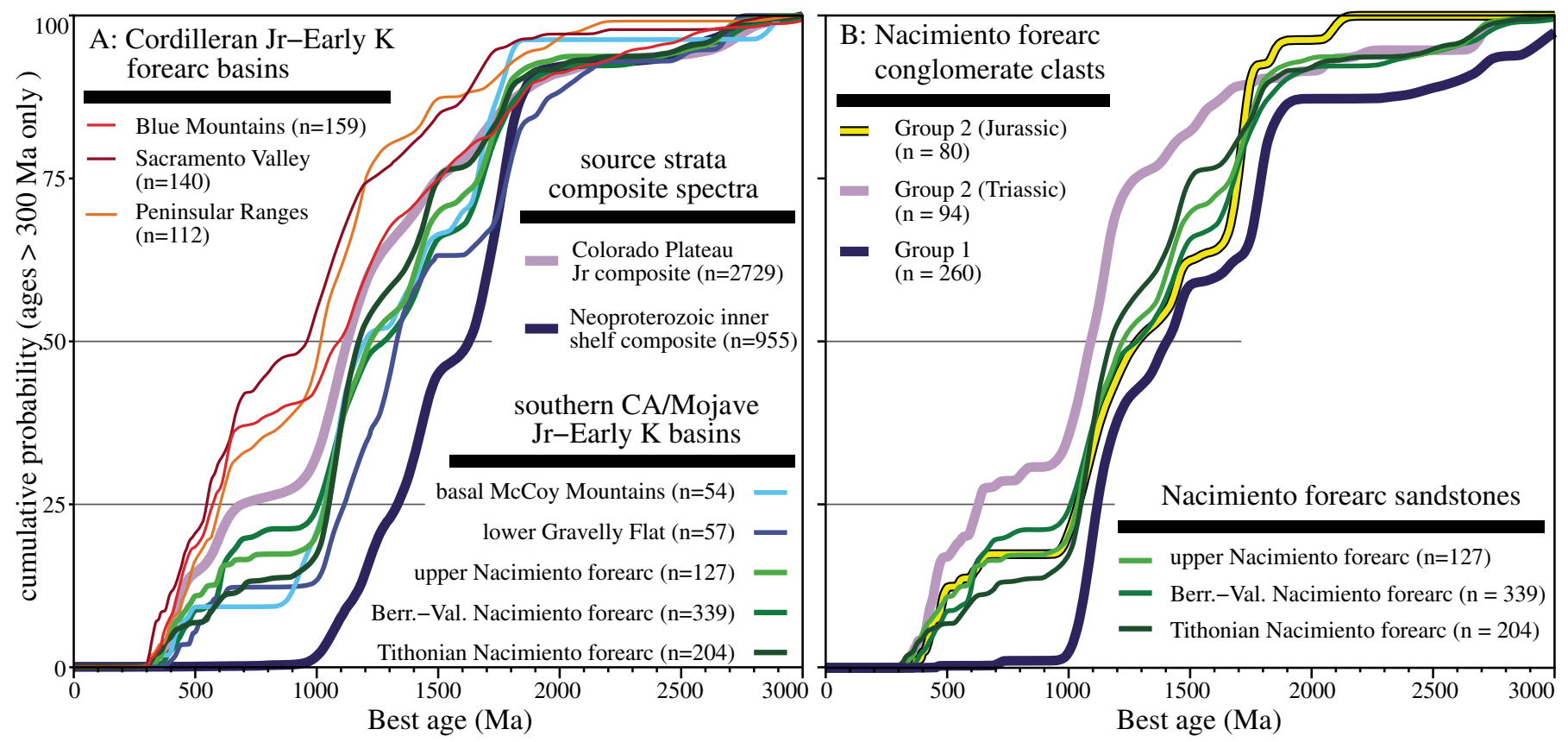

Figure 8. Detrital zircon geochronology cumulative probability plots for Precordilleran grains with ages older than 300 Ma from the North American Cordillera. (A) Comparison of Jurassic-Early Cretaceous strata of the Mesozoic convergent margin with source strata exposed in Colorado Plateau and North American miogeocline. Note that Jurassic-Early Cretaceous strata from southern California, Mojave Desert, and Nacimiento block yield less 700-300 Ma zircon than forearc strata elsewhere along the margin. (B) Comparison of Nacimiento conglomerate clasts and Nacimiento sandstone. For sample names and references for composite and individual source strata in A, see Appendix DR1 (text footnote 1). CA—California; Jr-Jurassic; $\mathrm{K}$-Cretaceous; Berr.-Val.-Berriasian-Valanginian.

sources (Fig. 7A): Middle Jurassic granitic rocks are exposed along the length of the Sierran-Peninsular Ranges arc (e.g., Paterson and Ducea, 2015), whereas Late Jurassic granitic rocks crop out widely in the Mojave Desert and eastern domains of the southern Sierra Nevada, and on the western flanks of the northern Sierra (Saleeby et al., 1989a; Barth et al., 2008). Early Cretaceous zircon in lower Nacimiento forearc sandstone displays a maximum at $138 \mathrm{Ma}$. Zircon of this age is less common in the Cordilleran arc, although plutonic rocks of this age are known from the Klamath Mountains (Allen and Barnes, 2006), in the western Sierra Nevada (Saleeby et al., 1989a; Saleeby et al., 1989b; Chapman et al., 2012; Clemens-Knott et al., 2013), and in basement core samples extracted from the southern San Joaquin Valley (Saleeby, 2007). Permian-Late Triassic zircon in lower Nacimiento forearc sandstone displays a maximum at ca. $259 \mathrm{Ma}$ and could have been derived from early Cordilleran magmatic sources in the east Mexico magmatic arc, which extends northwest from eastern Mexico through northern Sonora and to the northern Mojave Desert (Miller et al., 1995; Arvizu et al., 2009). Alternatively, the presence of conglomerate clasts that display sharp Permian zircon age maxima (e.g., conglomerate clast DF-p6) suggests that a significant component of Permian zircon in lower Nacimiento forearc sandstone could have been recycled from Triassic strata similar to southern tributary facies of the Chinle Group (e.g., Dickinson and Gehrels, 2008).
Petrographic results from lower Nacimiento forearc sandstone that plot near the border of recycled-orogen and transitionalarc fields on a QtFL diagram (Fig. 5) are generally consistent with detrital zircon results indicating a mixture of zircon recycled from Laurentian margin strata and arc sources. The increasing component of arc-derived zircon in successively younger lower Nacimiento forearc sandstone is also recorded by petrographic results that show Barremian-Valanginian sandstone with more lithic-rich compositions than Tithonian sandstone. Together, the detrital zircon and petrographic data suggest multiple source terranes for lower Nacimiento forearc sandstone characterized by a component of recycled Neoproterozoic-Paleoproterozoic and Triassic-Jurassic strata from the Mojave Desert, southern California, Arizona, or northernmost Mexico, which was progressively swamped by an increasing component of arc detritus derived from Jurassic-Early Cretaceous arcs.

\section{Upper Nacimiento Forearc Sandstone Provenance}

The pattern of increasing arc-derived zircon in successively younger sandstone continued through the Cretaceous, and Cordilleran zircon younger than $300 \mathrm{Ma}$ accounts for $81 \%, 89 \%$, and 92\% of total zircon in Lower Albian, Upper Albian-Cenomanian, and Upper Cenomanian-Santonian Nacimiento sandstone, respectively. Although rare, the average proportion of Precordilleran zircon in all upper Nacimiento forearc sandstone is similar to lower Nacimiento forearc sandstone in that 700-300 Ma 
zircon ages comprise only $17 \%$ of the Precordilleran zircon population. However, given the lack of evidence for Neoproterozoic-Paleozoic quartzite cobbles in Albian conglomerate and the appearance of a population of Jurassic sandstone cobbles that are similarly deficient in 700-300 Ma zircon, we infer that the Precordilleran zircon signature in upper Nacimiento forearc sandstone is primarily derived from a mixture of recycled zircon from Jurassic arc-flank and rift strata.

Cordilleran zircon younger than 300 Ma in upper Nacimiento forearc sandstone is dominated by 111-90 Ma zircon. Potential source terranes for these zircon are widespread throughout the Sierra Nevada and Peninsular Ranges arcs, which both display generally eastward migrating magmatism, as indicated by crystallization ages of 125-110 Ma in the western arc, 110 $100 \mathrm{Ma}$ in the central arc, and 100-85 Ma in the eastern arc (Chen and Moore, 1979; Silver et al., 1979; Premo et al., 2014). Age maxima that decrease from 109-108 to 107-103, and 100$95 \mathrm{Ma}$ in Lower Albian, Upper Albian-Cenomanian, and Upper Cenomanian-Santonian Nacimiento sandstone, respectively, indicate that source terranes migrated eastward with the active segment of the arc. The eastward migration of arc sediment sources to the forearc is further emphasized by the scarcity of zircon derived from the 125-110 Ma western arc in Albian and younger sediments. Eastward migration of arc sediment sources may be explained by the structural removal of western portions of the arc via subduction erosion (Chapman et al., 2016), although structures responsible for sequential removal of the western and central portions of the arc during the Albian have not been identified. Alternatively, eastward migration of arc sources in upper Nacimiento forearc strata may be analogous to progressive dilution of western arc detritus observed in Upper Cretaceous Sacramento and San Joaquin Valley forearc strata achieved through eastward migration of drainage divides and headward erosion of fluvial systems responding to gradual unroofing of the arc (Ingersoll, 1983; Linn et al., 1992; DeGraaff-Surpless et al., 2002; Sharman et al., 2015). However, while Sacramento and San Joaquin Valley forearc strata continued to receive abundant Jurassic and Early Cretaceous arc zircon older than 115 Ma through the Campanian (DeGraaff-Surpless et al., 2002), with the exception of Upper Albian-Lower Cenomanian strata (see discussion below), Albian and younger upper Nacimiento forearc strata are nearly devoid of arc zircon older than $115 \mathrm{Ma}$. As such, we infer that in addition to eastward headward erosion, arc sources adjacent to the Nacimiento block lacked long-lived highlands west of the active arc (e.g., DeGraaff-Surpless et al., 2002, their figure 12), and sediment derived from topographic highlands in active arc segments sufficiently diluted the detrital signal and/or physically buried older western arc segments. The possibility of localized elimination of western arc sources through subsidence and burial is supported by Cenomanian forearc strata that onlapped western segments of the arc in the San Joaquin Valley (Moxon, 1988), by Upper Cretaceous strata derived from the central and eastern arc overlying western arc basement in the southern San Joaquin Valley (Saleeby, 2007), and by Cenomanian-Turonian forearc strata in southern California that unconformably overlie segments of the western arc and that include volcanic conglomerate clasts derived from farther east (Herzig and Kimbrough, 2014).

Abundant Cretaceous zircon in Nacimiento block strata of Upper Albian-Cenomanian age is accompanied by a significant component of Jurassic zircon of 170-157 Ma age, which could have been derived from Middle Jurassic magmatic rocks that are widespread throughout the Cordilleran arcs (e.g., Chen and Moore, 1979; Shaw et al., 2003; Barth et al., 2017). Alternatively, McLean et al. (1977) described abundant mafic and ultramafic clasts in Cenomanian conglomerate of the San Rafael Mountains and argued that they were derived from source terranes composed largely of oceanic crust similar to the Coast Range ophiolite. Derivation of significant detritus from the Coast Range ophiolite is supported by the Jurassic detrital zircon age spectra in Cenomanian sandstone, which match 172-152 Ma U-Pb zircon ages from igneous rocks within the ophiolite (Hopson et al., 2008, and references therein), and by detrital zircon trace-element geochemistry consistent with derivation from oceanic crust (Johnston and Kylander-Clark, 2016). Although mafic rocks from oceanic crust are not typically associated with abundant zircon crystallization, the zircon fertility of the Coast Range ophiolite has been confirmed by detrital zircon geochronology and geochemistry of Miocene strata from the Nacimiento block also linked to the Coast Range ophiolite (Colgan and Stanley, 2016). Middle Jurassic detrital zircon is also abundant in ca. $100 \mathrm{Ma}$ forearc strata from the Gravelly Flat Formation in the southern San Joaquin Valley (Martin and Clemens-Knott, 2015), and recent detrital zircon geochemistry results suggest an oceanic crust source terrane (Mistretta et al., 2016). Based on this preliminary evidence, we hypothesize the presence of a highland in the Cenomanian outer forearc that exposed basement rocks of the Coast Range ophiolite and provided a source terrane for Jurassic zircon to the forearc basin (Fig. 7D). Although subaerial exposures within the Cenomanian forearc have not been previously been documented, a switch to wedge growth via frontal accretion and underplating at this time in the Nacimiento block and in southern California (Grove et al., 2008; Chapman et al., 2016) could have led to widespread uplift of the outer forearc high and the exhumation of the Jurassic ophiolite forearc basement (e.g., Platt, 1986; Grove et al., 2008).

The similarity of Middle Jurassic detrital zircon populations in Cenomanian forearc strata from the southern San Joaquin and the Nacimiento block may indicate a similar arc or forearc source terrane. However, Albian-middle Campanian forearc sandstone from the two regions are differentiated by arc zircon younger than $115 \mathrm{Ma}$ derived from the central and eastern arc, which is scarce in the San Joaquin Valley (DeGraaff-Surpless et al., 2002; Martin and Clemens-Knott, 2015). The ages of arc-derived detrital zircon can be used to distinguish Upper Cretaceous Cordilleran forearc strata, because relatively northern strata yield abundant 180-135 Ma zircon, whereas more southerly strata yield abundant 130-90 Ma zircon (Sharman et al., 2015; Chapman et al., 2016). Sharman et al. (2015) attributed increasingly abundant Jurassic-Early 
Cretaceous zircon in Upper Cretaceous forearc strata at more northerly latitudes to the obliquely trending geometry of Jurassic and Cretaceous arc rocks, which cross in the southern Sierra Nevada such that Jurassic granitic rocks are west of Cretaceous granitic rocks in northern California and east of Cretaceous granitic rocks in southern California and northernmost Mexico (Figs. 7C, 7D, and 7E). With the exception of Middle Jurassic zircon in Cenomanian sandstone, for which we infer a forearc source as discussed above, Albian and younger Nacimiento forearc sandstone is dominated by arc zircon younger than $111 \mathrm{Ma}$, which suggests an arc source terrane south of the southern San Joaquin Valley in southern California or Baja California.

\section{Upper Nacimiento Forearc Basin Accommodation Space and Convergent-Margin Dynamics}

Forearc strata of the San Joaquin Valley, the Nacimiento block, and Baja California indicate the presence of a regionally developed unconformity in the Early Cretaceous extending from the Valanginian-Hauterivian to the Aptian-Cenomanian (this study; Moxon, 1988; Kimbrough et al., 2001). This unconformity could record an erosional event caused by regional deformation and uplift in the forearc (Hopson et al., 1981; Moxon, 1988). However, the disconformable nature of the contact (Vedder et al., 1967; Dibblee and Minch, 2005) argues against significant deformation, uplift, and associated erosion during the Early Cretaceous. Alternatively, this disconformity could represent low depositional rates or even modest erosion during a period in which sediment bypassed this part of the forearc basin. Sediment bypass of the forearc basin could have occurred in response to low rates of sediment delivery to the forearc, which resulted in a slowly subsiding, nonaccretionary subduction complex, and ultimately, a forearc basin that was overfilled with respect to relatively low-standing topography in the outer forearc high (e.g., Noda, 2016).

Regardless of the cause of this unconformity, deposition in the middle forearc from the San Joaquin Valley to Baja California was reinitiated by the Aptian-Albian and was closely followed by rapid subsidence and the accumulation of thick sequences of clastic strata during the Late Cretaceous (Moxon and Graham, 1987; Moxon, 1988; Kimbrough et al., 2001). Accommodation space in forearc basins can be generated through diverse mechanisms, including sediment ponding behind an outer forearc wedge, flexural subsidence from the load of a growing outer forearc wedge or basin sediments, thermal subsidence of arc or ophiolite forearc basement (e.g., Dickinson, 1995), topographic variability within the wedge as it dynamically interacts with subducting oceanic lithosphere (Fuller et al., 2006), and subsidence due to subduction erosion of the basal forearc (Scholl et al., 1980). In the northern California forearc, the significance of wedge dynamics is emphasized by westward/seaward wedge growth (Ingersoll, 1982) associated with a switch from a nonaccretionary to accretionary wedge at ca. 123 Ma (Dumitru et al., 2010), and flexural subsidence related to wedge growth is thought to have been a primary driving force for forearc basin subsidence in the Cenomanian (Williams and Graham, 2013). In the Nacimiento block and in southern California, a pulse of rapid accretion in the subduction complex during the Cenomanian at 97-95 Ma has been documented (Grove et al., 2008; Chapman et al., 2016), although the initial burial of forearc thrust sheets by 120 $15 \mathrm{Ma}$, which were later incorporated into the wedge (Grove et al., 2008), suggests that the switch to an accretionary forearc in southern California may have occurred as early as the AptianAlbian. The possibility of a growing accretionary wedge in the Albian-Cenomanian Nacimiento forearc is supported by the presence of detritus derived from Jurassic ophiolitic basement hypothesized here to indicate significant uplift of the outer forearc prior to its exposure at the surface by ca. $100 \mathrm{Ma}$. As such, we suggest that the creation of accommodation space for upper Nacimiento forearc strata, and elsewhere within forearc basin exposures of the San Joaquin Valley, southern California, and Baja California, was largely controlled by growth and uplift of the adjacent forearc wedge subduction complex (Figs. 7C and 7D).

The coincidence in timing between subsidence in the AptianCenomanian forearc and increasing magmatism in the Cordilleran arc suggests the possibility of causal links between the dynamics of these segments of the convergent margin (Kimbrough et al., 2001). Initiation of Aptian-Albian forearc basin deposition was roughly coincident with 115-108 Ma arc contraction in the Peninsular Ranges batholith (Johnson et al., 1999), 125-103 Ma ductile deformation and granulite-facies metamorphism in the Sierran arc middle crust (Ducea, 2001), and 125-105 Ma magmatism in the western arc (Lackey et al., 2012; Premo et al., 2014) associated with a gradual increase in magmatic flux throughout the Cordillera (Barton et al., 1988; Ducea, 2001). Similarly, increased depositional rates in the forearc basin during the Cenomanian were coincident with 103-97 Ma contractional tectonism in the northern Peninsular Ranges (Premo and Morton, 2014), 110-80 Ma increased rates of contractional and dextral transpressional strain in the Sierra Nevada (Cao et al., 2015), and 105-85 Ma high-flux magmatism throughout the Sierra NevadaPeninsular Ranges arc (Ducea, 2001; Kimbrough et al., 2001).

Competing end-member models linking the dynamics of forearc and arc segments of the convergent margin suggest that accretionary-wedge growth and associated forearc-basin subsidence may have been controlled by (1) variable arc topography and orogenic-scale critical taper (DeCelles et al., 2009; DeCelles and Graham, 2015), or (2) variable sediment flux to the trench associated with uplift of the arc and/or retroarc (Dumitru et al., 2010, 2013). Orogenic-scale critical-taper models suggest that forearc wedge growth and arc magmatism should be out of phase, such that wedge propagation is fastest during magmatic lulls and slows as the orogen switches to a state of subcritical taper during periods of high magmatic flux, with a topographically low arc pulled down by the isostatic effects of its dense eclogitic root (DeCelles et al., 2009). Alternatively, modern 
accretionary forearc wedges are strongly correlated with high sediment supply to subduction trenches (Clift and Vannucchi, 2004). This correlation thus predicts that forearc wedge growth should, in fact, be in phase with arc uplift (Dumitru et al., 2010), given expected increases in sediment flux to the trench associated with arc uplift related to contraction and/or high magmatic rates (Lee et al., 2015).

Because forearc basin subsidence may directly reflect the growth of subduction complexes, as discussed above, these models can be tested by comparing the relative timing of forearc basin subsidence with respect to the timing of arc magmatism and elevation (Fig. 9). Relevant data from the Nacimiento block presented here document a disconformity from ca. 135 to $109 \mathrm{Ma}$ coincident with low arc magma flux during the Early Cretaceous magmatic lull, and a renewal of accommodation space in the Albian, either simultaneous with, or following a period of arc uplift that cut off interior continental detritus from the forearc. The arrival of more arkosic sand to the Nacimiento forearc by $96 \mathrm{Ma}$ indicates that forearc deposition was coincident with arc unroofing and exhumation. In orogenic critical-taper models, rapid foreland (retroarc) contraction and a relatively elevated arc during a magmatic lull could have formed a drainage divide between continental source terranes and the forearc basin. However, orogenic-scale critical taper, which predicts forearc-wedge propagation and growth during magmatic lulls, is not consistent with the apparent lack of subsidence in the forearc basin (and presumably feeble forearc wedge growth) from 135 to $109 \mathrm{Ma}$. Instead, the regional renewal of forearc basin subsidence in the Aptian-Albian, followed by rapid basin deposition in the Cenomanian (Kimbrough et al., 2001), suggests wedge growth

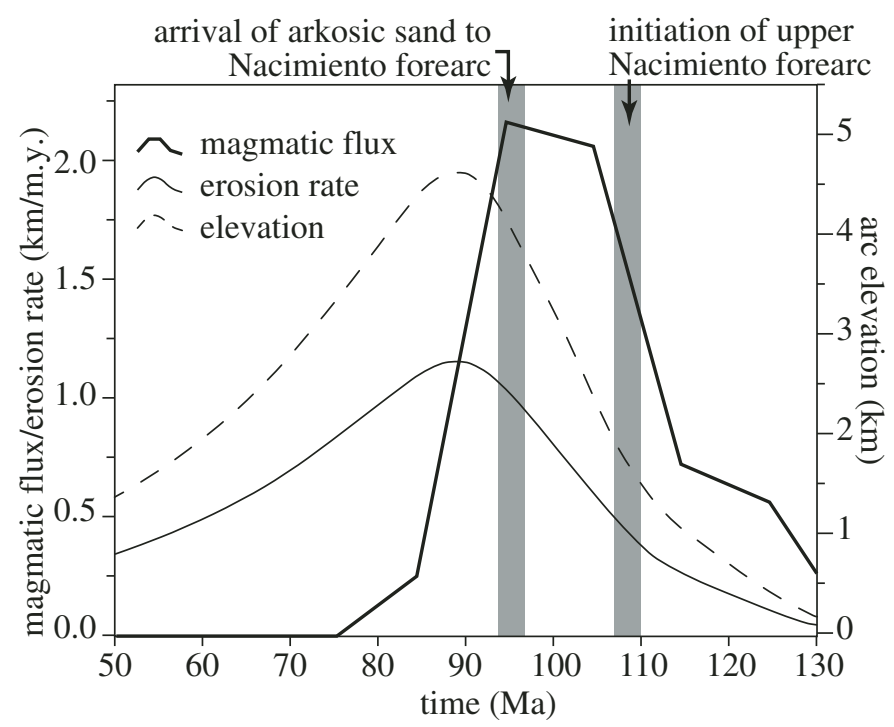

Figure 9. Comparison of timing of events within upper Nacimiento forearc to isostatic models of arc uplift and erosion based on assumed magma flux in Peninsular Ranges batholith (modified from Jiang and Lee, 2017). Magma flux assumes maximum crustal thickness of $60 \mathrm{~km}$, and arc erosion and elevation assume erosion response time of 4 m.y. occurred in phase with magma generation leading up to, and during the 105-85 Ma high-flux magmatic event. Furthermore, lowstanding arc topography during the high-flux event predicted by orogenic critical-taper models is not consistent with arc uplift and exhumation required for delivery of arkosic sand to the Nacimiento block forearc by $96 \mathrm{Ma}$. Instead, the timing of the initiation of upper Nacimiento basin deposition and subsequent infilling by arkosic sand is more consistent with isostatic modeling that suggests that Peninsular Ranges batholith topography and erosion rates increased shortly after the onset of high-flux magmatism at $110 \mathrm{Ma}$, before reaching a maximum at ca. $90 \mathrm{Ma}$ (Fig. 9; Jiang and Lee, 2017). We therefore suggest that the San Joaquin Valley, southern California, Nacimiento, and Baja California forearc was not coupled to the arc via critical taper, and we instead favor a model in which forearc wedge growth and resulting forearc basin accommodation space were controlled by sediment flux to the trench. In this model, increased sediment load to the trench during the Aptian-Albian could have been driven by uplift of the arc related to arc contraction and/or increased rates of intrusion at the beginning of the Cretaceous high-flux magmatic event. Even higher rates of forearc basin deposition during the Cenomanian could have been accomplished by similar mechanisms at the height of the Cretaceous high-flux magmatic event: Eastward migration, inflation, and uplift of the arc could have led to increasingly abundant sediment supply to the trench, increased rates of accretion within the subduction complex, and, ultimately, increased accommodation space in the forearc basin (Figs. 7C and 7D). Finally, we suggest that reduced middle Campanian depositional rates in the Nacimiento block and throughout the Cordilleran outer forearc (e.g., Moxon, 1988) may reflect a shift back to a nonaccretionary forearc regime coincident with the onset of Laramide flatslab subduction and the loss of flexural accommodation space as accretionary growth of the subduction complex stalled (Fig. 7E). Although it is beyond the scope of this paper, this model can be tested in future studies that more precisely date the timing of the Early Cretaceous unconformity and increased sedimentation rates and arkosic infilling in correlative stretches of the forearc basin exposed in the San Joaquin Valley, southern California, and Baja California for comparison with the timing of magmatism and uplift in adjacent segments of the arc.

\section{Paleogeographic Origin of the Nacimiento Block}

Existing paleogeographic models for central and southern California alternately suggest northerly (e.g., Dickinson, 1983; Seiders, 1983; Jacobson et al., 2011) or southerly (e.g., Hall, 1991; Chapman et al., 2016) paleogeographic origins for the Nacimiento block (Fig. 10A). Detrital zircon results discussed herein strongly link Cretaceous Nacimiento block forearc sediments to source terranes in southern California, Arizona, and northernmost Mexico. This southern provenance does not immediately rule out a more northerly paleogeographic origin for the Nacimiento block, given north-directed paleocurrent indicators in 
Tithonian-Cenomanian strata of the Nacimiento block (Seiders, 1983), and evidence for up to $500 \mathrm{~km}$ of axis-parallel transport of sediment within forearc basins (e.g., the Kione-Forbes submarine fan; Dumitru et al., 2016). However, paleoenvironmental analysis of Cenomanian-Campanian strata from the San Rafael Mountains documents $700 \mathrm{~m}$ of Cenomanian inner-fan-channel conglomerate overlain by midfan deposits that suggest a smaller fan system, $<10 \mathrm{~km}$ wide located proximal to the shelf-slope break (Nelson, 1979), and this provides evidence against long-distance, north-directed, axis-parallel sediment transport. Notably, Upper Albian-Cenomanian and Upper Cenomanian-Santonian strata from this fan system display paleocurrent indicators that shift from north-directed to south-directed with time (McLean et al., 1977; Nelson, 1979). Because detrital zircon populations from both Upper Albian-Cenomanian and Upper CenomanianSantonian strata in this fan yield abundant Cretaceous zircon younger than $111 \mathrm{Ma}$ (this study), these paleocurrent data support southern California arc source terranes (where the Cretaceous arc is located to the west of the Jurassic arc) positioned to the north and south of this fan system. Finally, if Cenomanian strata in the Nacimiento block are composed of a mixture of detritus from the Cretaceous arc and ophiolitic Jurassic forearc basement (as proposed in this study), then they make an original position outboard of central California unlikely, given that Cenomanian strata from the Gravelly Flat Formation in the southern San Joaquin Valley are dominated by Jurassic ophiolitic forearc basement but lack abundant Cretaceous arc detritus (Martin and Clemens-Knott, 2015; Mistretta et al., 2016). For example, it is difficult to imagine a scenario in which the southern San Joaquin and Nacimiento segments of the forearc could have both received detritus from western sources in the outer forearc ridge while Late Cretaceous central arc detritus reached the relatively outboard Nacimiento forearc but bypassed the relatively inboard southern San Joaquin forearc (Fig. 7D). The sum of these arguments leads us to conclude that the Nacimiento block was originally positioned south of the southern San Joaquin Valley and off the coast of southern
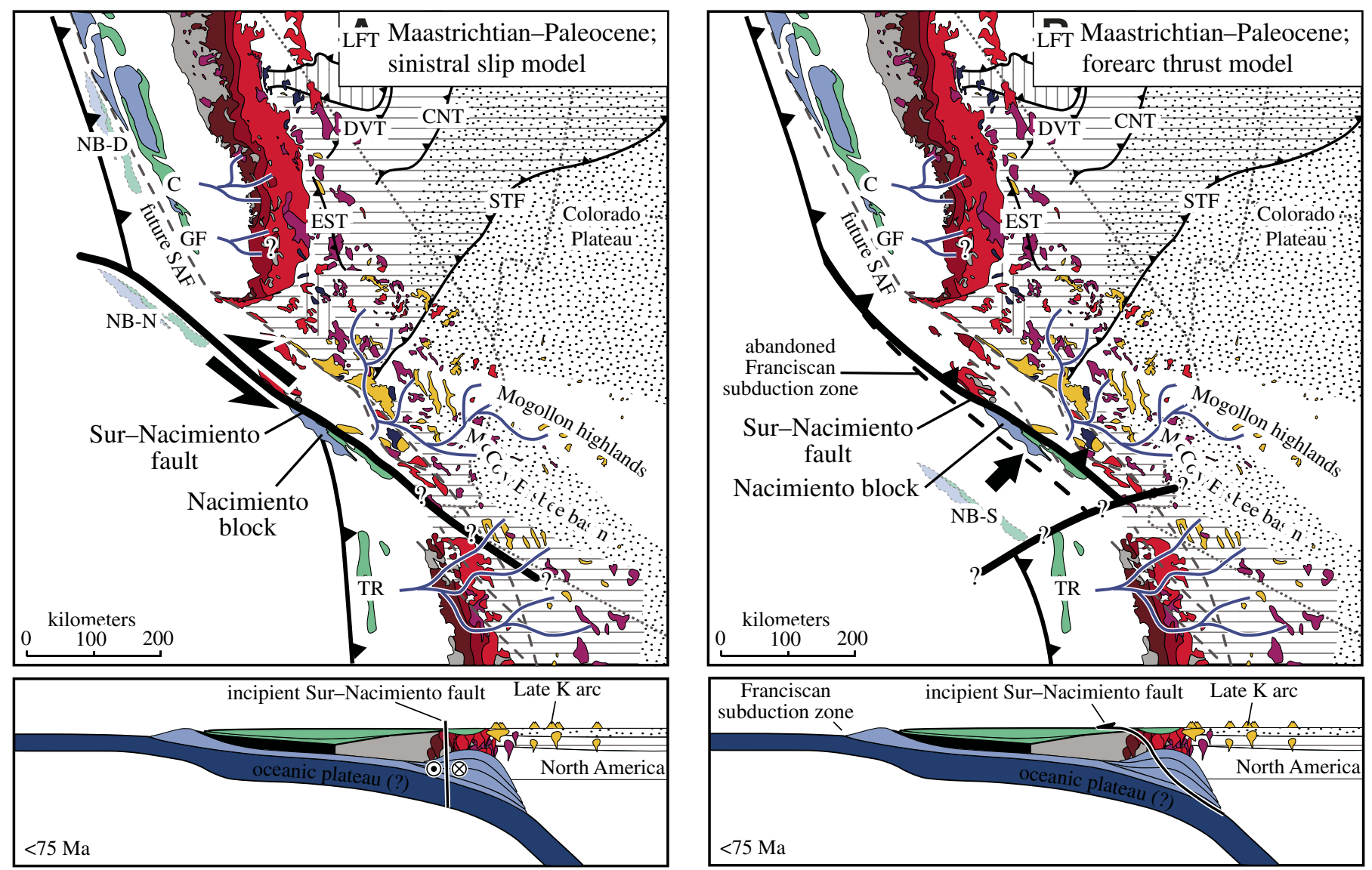

Figure 10. Maps and cross sections illustrating (A) sinistral-slip and (B) forearc-thrust models for evolution of Sur-Nacimiento fault. To more completely illustrate details of each model, maps have been drawn after displacement along fault, and cross sections are drawn just before fault displacement. NB-D in A indicates paleogeographic origin for Nacimiento block outboard of Diablo Range, hypothesized in previously published models of the sinistral-slip model (e.g., Dickinson, 1983; Seiders, 1983; Jacobson et al., 2011). See text for further discussion. Map symbols and abbreviations are same as in Figure 7. 
California or northern Baja California (e.g., NB-N or NB-S in Figs. 7 and 10).

\section{Kinematic Evolution of the Sur-Nacimiento Fault}

The new constraints on the paleogeographic origin of the Nacimiento block presented here, as well as recent pre-San Andreas fault reconstructions of the Salinian block in southern California (Sharman et al., 2013, 2015), warrant discussion and reevaluation of existing models for the evolution of the SurNacimiento fault. Juxtaposition of Salinian block central and eastern arc crust against the Nacimiento block forearc suggests a minimum of $150 \mathrm{~km}$ of Sur-Nacimiento fault slip associated with omission of the majority of the inner forearc basin and the western arc (e.g., Page, 1970). Salinian block basement rocks, characterized by 76 Ma granulite-facies metamorphism (Kidder et al., 2003), and arc intrusive rocks as young as 78-76 Ma (Mattinson, 1990) require a typical arc-trench gap adjacent to Salinia at that time and provide an older age limit for the removal of its forearc via slip on the Sur-Nacimiento fault. Lower Eocene strata that are interpreted to overlap the fault provide a younger age limit of $56 \mathrm{Ma}$ for Sur-Nacimiento fault slip, although this age limit is poorly defined and may be as old as $62.5 \mathrm{Ma}$ (see discussion in Jacobson et al., 2011).

Existing kinematic models for the Sur-Nacimiento fault alternately call for dextral, sinistral, thrust, or normal displacement along the fault. Dextral models suggest an equatorial latitude for the paleogeographic origin of the Nacimiento block, with subsequent emplacement in southern California via one or more margin-parallel faults (McWilliams and Howell, 1982; Page, 1982; Wright and Wyld, 2007). However, dextral strike-slip models are not consistent with a Nacimiento block origin in southern California or northern Baja California or the lack of evidence for 1000-950 Ma detrital zircon age maxima in Nacimiento forearc strata sourced from southern Mexico basement rocks (Wright and Wyld, 2007). Alternatively, Chapman et al. (2016) noted the coincidence in timing between Sur-Nacimiento fault slip and Late Cretaceous collapse of the southern Sierran arc and suggested that the fault may represent a low-angle detachment that accommodated significant normal-sense displacement. Although we do not rule out the possibility that the Sur-Nacimiento fault may have been reactivated as a normal fault at a later time, initial activation of the Sur-Nacimiento fault as a normal fault is not consistent with evidence against burial of Nacimiento block forearc basin strata (which resided in the lower plate of this hypothetical low-angle detachment) to metamorphic depths, or the observation that the Sur-Nacimiento fault is associated with at least $150 \mathrm{~km}$ of post-76 Ma missing forearc. As such, dextral and extensional models are not considered further in this manuscript, and the remainder of this discussion focuses on sinistral and contractional models for Sur-Nacimiento fault slip.

Sinistral models suggest that the Sur-Nacimiento fault cut out the forearc basin as the Nacimiento block was translated $550-575 \mathrm{~km}$ southeastward from an original position outboard of the Diablo Range (e.g. NB-D in Fig. 10A), obliquely across the Mesozoic margin, and into contact with the Salinian block (Dickinson, 1983; Seiders, 1983; Jacobson et al., 2011). This model is clearly not consistent with the interpretation presented here that the Nacimiento block originated south of the southern San Joaquin Valley. However, a Nacimiento block origin just south of the southern San Joaquin Valley (NB-N in Figs. 7 and 10A) does not preclude a model for sinistral slip revised here to include significantly less displacement (Fig. 10A). Rather than turning to the north and parallel to the forearc north of southern California (e.g., Jacobson et al., 2011), the map pattern of the Sur-Nacimiento fault in this revised model would have cut obliquely across the ancestral forearc, and this is perhaps more consistent with betterconstrained segments of the Sur-Nacimiento fault in central and southern California that strike obliquely across the arc. Sinistral slip along a fault trending obliquely to the Cordilleran margin also provides an elegant explanation for the apparent left step between the Sierran and Peninsular Ranges segments of the arc observed in pre-San Andreas fault reconstructions of southern California, as well as a pathway for retroarc detritus across the arc to the Paleocene-Eocene forearc (e.g., Jacobson et al., 2011). Because plate-motion vectors indicate approximately normal convergence between the Farallon and North American plates in the Late Cretaceous (Engebretson et al., 1985), Jacobson et al. (2011) argued that a sinistral Sur-Nacimiento fault may represent an escape structure caused by interaction of an aseismic ridge with the North American margin. However, Sur-Nacimiento fault slip must have postdated emplacement of 76 Ma Salinian block granitic rocks (Mattinson, 1990), whereas the Shatsky Ridge is thought to have collided with North America by ca. $90 \mathrm{Ma}$ and passed beneath the Colorado Plateau at ca. $75 \mathrm{Ma}$ (Liu et al., 2010). As such, the timing of Sur-Nacimiento fault slip is not consistent with its interpretation as an escape structure, and a viable mechanism for the generation of sinistral slip within the Late Cretaceous Cordilleran forearc represents a significant problem for sinistral strike-slip models for the Sur-Nacimiento fault.

Alternatively, contractional models for Sur-Nacimiento fault slip suggest that it represents a thrust contact, along which the forearc basin was buried and Salinian magmatic rocks were placed above Nacimiento block subduction complexes (Page, 1970; Hall, 1991; Hall and Saleeby, 2013). This model is consistent with the interpretation presented here that the Nacimiento block originated south of the southern San Joaquin Valley or in northern Baja California (e.g., NB-S in Figs. 7 and 10B). An advantage of thrust models for Sur-Nacimiento fault displacement over sinistral strike-slip models, which lack a viable tectonic explanation for the generation of slip, is that post-76 Ma thrust displacement can be explained by processes associated with subduction erosion of a large forearc block in southern California. Within the context of wedge dynamics, the subduction of large forearc blocks (including the forearc basin and segments of the arc) represents an out-of-sequence thrust that can form when the strength of the basal thrust exceeds the internal strength of its overlying wedge (Davis et al., 1983). Thermomechanical models 
suggest that the subduction of large forearc blocks may occur as intraplate strain is transferred arcward from the subduction zone, and this is favored in margins with strong subduction shear zones characterized by shallow subduction angles and/or stronger rocks with relatively high angles of internal friction (Keppie et al., 2009). From 70 to $60 \mathrm{Ma}$, the tectonic setting of southern California was characterized by a flat segment of the Laramide slab, removal of the forearc mantle lithosphere, and subduction erosion of the frontal wedge and its subsequent underplating as the Pelona-Orocopia-Rand Schist beneath the arc (Grove et al., 2003, 2008; Jacobson et al., 2011; Chapman, 2017). Because out-of-sequence thrusting of a large forearc block is generally consistent with subhorizontal subduction beneath the Late Cretaceous southern California forearc, this model thus presents an attractive mechanism for Paleocene transfer of intraplate strain from a segment of the Franciscan subduction zone to thrust displacement along the Sur-Nacimiento fault (Fig. 10B).

Despite this viable mechanism for thrust displacement along the Sur-Nacimiento fault, the thrust model is hampered by several unresolved questions. In particular, thrust models dictate that Sur-Nacimiento fault slip occurred after ca. 70-65 Ma emplacement of the Pelona-Orocopia-Rand Schist and before 62.5$56 \mathrm{Ma}$ stratigraphic constraints (see discussion in Jacobson et al., 2011, 2017). Although subduction of large forearc blocks can occur rapidly at essentially plate-tectonic rates in thermomechanical models (Keppie et al., 2009), the tight time constraints for Sur-Nacimiento fault slip highlight the fact that thrust models may need to be reevaluated as the resolution on the timing of Pelona-Orocopia-Rand Schist emplacement is improved. The thrust model is also hampered by its known map pattern, which cuts obliquely across, and deeply into the easternmost Salinian arc (e.g., the reconstructions of Sharman et al., 2015); this architecture is not consistent with margin-perpendicular displacement assumed by subduction erosion of large forearc blocks. Furthermore, how this shortening abruptly decreased to the south, or was transferred to shear zones that circumvented the Peninsular Ranges (which still displays its original arc width) cannot be explained by structures that are currently mapped in southern California (Fig. 10B). Ultimately, our new paleogeographic constraints that place the Nacimiento block south of the San Joaquin Valley cannot resolve the sinistral versus thrust history of the Sur-Nacimiento fault, and further work detailing the timing, as well as the nature of Late Cretaceous shear zones in southern California is needed.

\section{CONCLUSIONS}

This study couples conglomerate clast detrital zircon geochronology with sandstone petrography and detrital zircon geochronology from Late Jurassic-Cretaceous Nacimiento block forearc basin strata. Our results document the incorporation of a mixture of arc and continental detritus into the lower Nacimiento forearc, an unconformity from ca. 135 to $110 \mathrm{Ma}$, and detritus dominantly derived from the Late Cretaceous arc within the upper Nacimiento forearc. We infer a paleogeographic origin for the Nacimiento block south of the southern San Joaquin Basin in southern California or northern Baja California, based on: (1) detrital zircon age spectra from conglomerate clasts and sandstone that indicate the presence of detrital zircon recycled from the Neoproterozoic-Paleozoic North American miogeoclinal shelf and overlying strata of the Colorado Plateau, (2) a unique population of Middle Jurassic detrital zircon in Upper AlbianCenomanian sandstone, and (3) abundant Late Cretaceous arc zircon grains in north- and south-directed, inner- and midfan deposits from the upper Nacimiento forearc, which contrast with abundant Jurassic and Early Cretaceous arc zircon found farther north in coeval forearc deposits of the Sacramento and San Joaquin Valley.

Based on the timing of the Early Cretaceous forearc unconformity in the Nacimiento block and adjacent stretches of the forearc basin, we developed a model in which forearc accommodation space in the Late Cretaceous forearc basins of southern California and Baja California was driven by a switch to an accretionary regime in the adjacent subduction complex. Because the timing of this hiatus occurred during the Early Cretaceous magmatic lull, it supports regional tectonic models that couple the accretionary versus nonaccretionary tectonic regime in the subduction complex with sediment supply rather than with margin-scale wedge dynamics. Similarly, the inferred paleogeographic origin of the Nacimiento block south of the southern San Joaquin Valley has regional tectonic implications with respect to the evolution of the Sur-Nacimiento fault. This paleogeographic constraint requires the revision of sinistral strike-slip models to displacements $<300 \mathrm{~km}$, and it highlights weaknesses with both sinistral-slip and thrust models for the Sur-Nacimiento fault.

\section{ACKNOWLEDGMENTS}

This work was supported by American Chemical Society Petroleum Research Fund grant 51941-UNI8 (to Scott Johnston) and National Science Foundation grant EAR-PF-1250070 (to Alan Chapman). We acknowledge encouragement from Gary Ernst and Kathy Surpless, and thoughtful conversations with Carl Jacobson, Marty Grove, and Steve Graham, as well as constructive manuscript reviews from Trevor Dumitru, Glenn Sharman, and Ray Ingersoll. We also note that, from our understanding of forearc basins to the tectonics of the central California coast, to sandstone petrography and detrital zircon provenance studies of the Colorado Plateau, this work rests upon Bill Dickinson's tremendous contributions to the geological sciences.

\section{REFERENCES CITED}

Allen, C.M., and Barnes, C.G., 2006, Ages and some cryptic sources of Mesozoic plutonic rocks in the Klamath Mountains, California and Oregon, in Snoke, A.W., and Barnes, C.G., eds., Geological Studies in the Klamath Mountains Province, California and Oregon: A Volume in Honor of William P. Irwin: Geological Society of America Special Paper 410, p. 223-245, https://doi.org/10.1130/2006.2410(11).

Anczkiewicz, R., Platt, J., Thirlwall, M.F., and Wakabayashi, J., 2004, Franciscan subduction off to a slow start: Evidence from high-precision Lu-Hf 
garnet ages on high grade-blocks: Earth and Planetary Science Letters, v. 225, p. 147-161, https://doi.org/10.1016/j.epsl.2004.06.003.

Arvizu, H.E., Iriondo, A., Izaguirre, A., Chavez-Cabello, G., Kamenov, G.D. Solis-Pichardo, G., Foster, D.A., and Lozano-Santa Cruz, R., 2009, Rocas graníticas pérmicas en la Sierra Pinta, NW de Sonora, México: Magmatismo de subducción asociado al inicio del margen continental activo del SW de Norteamérica: Revista Mexicana de Ciencias Geológicas, v. 26, p. 709-728.

Atwater, T.M., 1989, Plate tectonic history of the northeast Pacific and western North America, in Winterer, E.L., Hussong, D.M., and Decker, R.W., eds., The Eastern Pacific Ocean and Hawaii: Boulder, Colorado, Geological Society of America, Geology of North America, v. N, p. 21-72.

Barnes, D.A., 1984, Volcanic arc derived, Mesozoic sedimentary rocks, Vizcaino Peninsula, Baja California Sur, Mexico, in Frizzel, V.A., ed., Geology of the Baja California Peninsula: Los Angeles, California, Pacific Section, Society of Economic Paleontologists and Mineralogists (SEPM), Book 39, p. 119-130.

Barth, A.P., Wooden, J.L., Jacobson, C.E., and Probst, K., 2004, U-Pb geochronology and geochemistry of the McCoy Mountains Formation, southeastern California: A Cretaceous retroarc foreland basin: Geological Society of America Bulletin, v. 116, p. 142-153, https://doi.org/10.1130/ B25288.1.

Barth, A.P., Wooden, J.L., Howard, K.A., and Richards, J.L., 2008, Late Jurassic plutonism in the southwest U.S. Cordillera, in Wright, J.E., and Shervais, J.W., eds., Ophiolites, Arcs, and Batholiths: A Tribute to Cliff Hopson: Geological Society of America Special Paper 434, p. 379-396, https://doi.org/10.1130/2008.2438(13).

Barth, A.P., Wooden, J.L., Miller, D.M., Howard, K.A., Fox, L.K., Schermer, E.R., and Jacobson, C.E., 2017, Regional and temporal variability of melts during a Cordilleran magma pulse: Age and chemical evolution of the Jurassic arc, eastern Mojave Desert, California: Geologic Society of America Bulletin, v. 129, p. 429-448.

Barton, M.D., Battles, D.A., Bebout, G.E., Capo, R.C., Christensen, J.N., Davis, S.R., Hanson, R.B., Michelsen, C.J., and Trim, H.E., 1988, Mesozoic contact metamorphism in the western United States, in Ernst, W.G., ed., Metamorphism and Crustal Evolution of the Western United States (Rubey Volume VII): Englewood Cliffs, New Jersey, Prentice Hall, p. 110-178.

Busby, C.J., Smith, D., Morris, W., and Fackler-Adams, B.N., 1998, Evolutionary model for convergent margins facing large ocean basins; Mesozoic Baja California, Mexico: Geology, v. 26, p. 227-230, https://doi.org/ 10.1130/0091-7613(1998)026<0227:EMFCMF>2.3.CO;2.

Cao, W., Paterson, S., Memeti, V., Mundil, R., Anderson, J.L., and Schmidt, K., 2015, Tracking paleodeformation fields in the Mesozoic central Sierra Nevada arc: Implications for intra-arc cyclic deformation and arc tempos: Lithosphere, v. 7, p. 296-320, https://doi.org/10.1130/L389.1.

Chapman, A.D., 2017, The Pelona-Orocopia-Rand and related schists of southern California: A review of the best-known archive of shallow subduction on the planet: International Geology Review, v. 59, p. 1-38.

Chapman, A.D., Saleeby, J.B., Wood, D.J., Piasecki, A., Kidder, S., Ducea, M.N., and Farley, K.A., 2012, Late Cretaceous gravitational collapse of the southern Sierra Nevada batholith, California: Geosphere, v. 8, p. 314 341, https://doi.org/10.1130/GES00740.1.

Chapman, A.D., Ernst, W.G., Gottlieb, E., Powerman, V., and Metzger, E.P., 2015 Detrital zircon geochronology of Neoproterozoic-Lower Cambrian passivemargin strata of the White-Inyo Range, east-central California: Implications for the Mojave-Snow Lake fault hypothesis: Geological Society of America Bulletin, v. 127, p. 926-944, https://doi.org/10.1130/B31142.1.

Chapman, A.D., Jacobsen, C.E., Ernst, W.G., Grove, M., Dumitru, T.A., Hourigan, J.K., and Ducea, M.N., 2016, Assembling the world's type shallow subduction complex: Detrital zircon geochronologic constraints on the origin of the Nacimiento block, central California Coast Ranges: Geosphere, v. 12, p. 533-557, https://doi.org/10.1130/GES01257.1.

Chen, J., and Moore, J.G., 1979, Late Jurassic Independence dike swarm in eastern California: Geology, v. 7, p. 129-133, https://doi.org/10.1130/0091 -7613(1979)7<129:LJIDSI>2.0.CO;2.

Clemens-Knott, D., van der Kolk, D.A., Sturmer, D., and Saleeby, J., 2013 , The Goldstein Peak Formation, central California: Record of a nonmarine intra-arc basin within the Early Cretaceous Sierra Nevada arc: Geosphere, v. 9, p. 718-735, https://doi.org/10.1130/GES00886.1.

Clift, P., and Vannucchi, P., 2004, Controls on tectonic accretion versus erosion in subduction zones: Implications for the origin and recycling of the continental crust: Reviews of Geophysics, v. 42, RG2001, https://doi .org/10.1029/2003RG000127.

Colgan, J.P., and Stanley, R.G., 2016, The Point Sal-Point Piedras Blancas correlation and the problem of slip on the San Gregorio-Hosgri fault, central California Coast Ranges: Geosphere, v. 12, p. 971-984, https://doi .org/10.1130/GES01289.1.

Davis, D., Suppe, J., and Dahlen, F.A., 1983, Mechanics of fold-and-thrust belts and accretionary wedges: Journal of Geophysical Research, v. 88, p. 1153-1172, https://doi.org/10.1029/JB088iB02p01153.

DeCelles, P.G., and Graham, S.A., 2015, Cyclical processes in the North American Cordilleran orogenic system: Geology, v. 43, p. 499-502, https://doi .org/10.1130/G36482.1.

DeCelles, P.G., Ducea, M.N., Kapp, P., and Zandt, G., 2009, Cyclicity in Cordilleran orogenic systems: Nature Geoscience, v. 2, p. 251-257, https:// doi.org/10.1038/ngeo469.

DeGraaff-Surpless, K., Graham, S.A., Wooden, J.L., and McWilliams, M., 2002, Detrital zircon provenance analysis of the Great Valley Group, California: Evolution of an arc-forearc system: Geological Society of America Bulletin, v. 114, p. 1564-1580, https://doi.org/10.1130/0016 -7606(2002)114<1564:DZPAOT>2.0.CO;2.

Dibblee, T.W., 1966, Geology of the Central Santa Ynez Mountains, Santa Barbara County, California: California Division of Mines and Geology Bulletin 186, $99 \mathrm{p}$

Dibblee, T.W., and Minch, J.A., 2005, Geologic Map of the Bald Mountain Quadrangle, Santa Barbara County, California: Dibblee Geological Foundation Map DF-186, scale 1:24,000.

Dickinson, W.R., 1983, Cretaceous sinistral strike slip along the Nacimiento fault in Coastal California: American Association of Petroleum Geologists Bulletin, v. 67, p. 624-645.

Dickinson, W.R., 1995, Forearc basins, in Busby, C.J., and Ingersoll, R.V., eds., Tectonics of Sedimentary Basins: Cambridge, UK, Blackwell Science, p. 221-262.

Dickinson, W.R., and Gehrels, G.E., 2008, U-Pb ages of detrital zircons in relation to paleogeography: Triassic paleodrainage networks and sediment dispersal across southwest Laurentia: Journal of Sedimentary Research, v. 78, p. 745-764, https://doi.org/10.2110/jsr.2008.088.

Dickinson, W.R., and Gehrels, G., 2009a, U-Pb ages of detrital zircons in Jurassic eolian and associated sandstones of the Colorado Plateau: Evidence for transcontinental dispersal and intraregional recycling of sediment: Geological Society of America Bulletin, v. 121, p. 408-433, https://doi .org/10.1130/B26406.1.

Dickinson, W.R., and Gehrels, G.E., 2009b, Use of U-Pb ages of detrital zircons to infer maximum depositional ages of strata: A test against a Colorado Plateau Mesozoic database: Earth and Planetary Science Letters, v. 288, p. 115-125, https://doi.org/10.1016/j.eps1.2009.09.013.

Dickinson, W.R., and Gehrels, G.E., 2010, Insights into North American paleogeography and paleotectonics from $\mathrm{U}-\mathrm{Pb}$ ages of detrital zircons in Mesozoic strata of the Colorado Plateau: International Journal of Earth Sciences, v. 99, p. 1247-1265, https://doi.org/10.1007/s00531-009-0462-0.

Dickinson, W.R., and Seely, D., 1979, Structure and stratigraphy of forearc regions: American Association of Petroleum Geologists Bulletin, v. 63 p. 2-31.

Dickinson, W.R., Beard, L.S., Brakenridge, R.R., Erjavec, J.L., Ferguson, R.C., Inman, K.F., Knepp, R.A., Lindberg, F.A., and Ryberg, P.T., 1983, Provenance of North American Phanerozoic sandstones in relation to tectonic setting: Geological Society of America Bulletin, v. 94, p. 222-235, https:// doi.org/10.1130/0016-7606(1983)94<222:PONAPS>2.0.CO;2.

Dickinson, W.R., Ducea, M., Rosenberg, L.I., Greene, H.G., Graham, S.A., Clark, J.C., Weber, G.E., Kidder, S., Ernst, W.G., and Brabb, E.E., 2005, Net Dextral Slip, Neogene San Gregorio-Hosgri Fault Zone, Coastal California: Geologic Evidence and Tectonic Implications: Geological Society of America Special Paper 391, 43 p.

Ducea, M., 2001, The California arc: Thick granitic batholiths, eclogitic residues, lithospheric-scale thrusting and magmatic flare-ups: GSA Today, v. 11, no. 11, p. 4-10, https://doi.org/10.1130/1052-5173(2001)011<0004 :TCATGB $>2.0 . \mathrm{CO} ; 2$

Dumitru, T.A., Wakabayashi, J., Wright, J.E., and Wooden, J.L., 2010, Early Cretaceous (ca. $123 \mathrm{Ma}$ ) transition from nonaccretionary behavior to strongly accretionary behavior within the Franciscan subduction complex: Tectonics, v. 29, TC5001, https://doi.org/10.1029/2009TC002542.

Dumitru, T.A., Ernst, W., Wright, J.E., Wooden, J.L., Wells, R.E., Farmer, L.P., Kent, A.J.R., and Graham, S.A., 2013, Eocene extension in Idaho 
generated massive sediment floods into the Franciscan trench and into the Tyee, Great Valley, and Green River basins: Geology, v. 41, p. 187-190, https://doi.org/10.1130/G33746.1.

Dumitru, T.A., Ernst, W.G., Hourigan, J.K., and McLaughlin, R.J., 2015, Detrital zircon $\mathrm{U}-\mathrm{Pb}$ reconnaissance of the Franciscan subduction complex in northwestern California: International Geology Review, v. 57, p. 767800, https://doi.org/10.1080/00206814.2015.1008060

Dumitru, T.A., Elder, W.P., Hourigan, J.K., Chapman, A.D., Graham, S.A., and Wakabayashi, J., 2016, Four Cordilleran paleorivers that connected Sevier thrust zones in Idaho to depocenters in California, Washington, Wyoming, and, indirectly, Alaska: Geology, v. 44, p. 75-78, https://doi.org/10.1130/G37286.1.

Engebretson, D.C., Cox, A., and Gordon, R.G., 1985, Relative Motion between Oceanic and Continental Plates in the Pacific Basin: Geological Society of America Special Paper 206, 60 p., https://doi.org/10.1130/SPE206-p1.

Fuller, C.W., Willett, S.D., and Brandon, M.T., 2006, Formation of forearc basins and their influence on subduction zone earthquakes: Geology, v. 34, p. 65-68, https://doi.org/10.1130/G21828.1.

Gehrels, G., Rusmore, M., Woodsworth, G., Crawford, M., Andronicos, C., Hollister, L., Patchett, J., Ducea, M., Butler, R., Klepeis, K., Davidson, C., Friedman, R., Haggart, J., Mahoney, B., et al., 2009, U-Th-Pb geochronology of the Coast Mountains batholith in north-coastal British Columbia: Constraints on age, petrogenesis, and tectonic evolution: Geological Society of America Bulletin, v. 121, p. 1341-1361, https://doi .org/10.1130/B26404.1.

Gilbert, W.G., and Dickinson, W.R., 1970, Stratigraphic variations in sandstone petrology, Great Valley Sequence, central California Coast: Geological Society of America Bulletin, v. 81, p. 949-954, https://doi.org/ 10.1130/0016-7606(1970)81[949:SVISPG]2.0.CO;2.

Grove, M., Jacobson, C.E., Barth, A.P., and Vucic, A., 2003, Temporal and spatial trends of Late Cretaceous-Early Tertiary underplating of Pelona and related schist beneath southern California and southwestern Arizona, in Johnson, S.E., Paterson, S.R., Fletcher, J.M., Girty, G.H., Kimbrough, D.L., and Martín-Barajas, A., eds., Tectonic Evolution of Northwestern Mexico and the Southwestern USA: Geological Society of America Special Paper 374, p. 381-406, https://doi.org/10.1130/0-8137-2374-4.381.

Grove, M., Bebout, G.E., Jacobson, C.E., Barth, A.P., Kimbrough, D.L., King, R.L., Zou, H., Lovera, O.M., Mahoney, B.J., and Gehrels, G.G., 2008, The Catalina Schist: Evidence for middle Cretaceous subduction erosion of southwestern North America, in Draut, A.E., Clift, P.D., and Scholl, D.W., eds., Formation and Applications of the Sedimentary Record in Arc Collision Zones: Geological Society of America Special Paper 436, p. 335-361, https://doi.org/10.1130/2008.2436(15).

Hall, C.A., 1981, Map of Geology along the Little Pine Fault, Parts of the Sisquoc, Foxen Canyon, Zaca Lake, Bald Mountain, Los Olivos, and Figureroa Mountain Quadrangles, Santa Barbara County, California: U.S. Geological Survey Miscellaneous Field Studies Map MF1285.

Hall, C.A., 1991, Geology of the Point Sur-Lopez Point Region, Coast Ranges, California: A Part of the Southern California Allochthon: Geological Society of America Special Paper 266, 40 p.

Hall, C.A., and Saleeby, J.B., 2013, Salinia revisited: A crystalline nappe sequence lying above the Nacimiento fault and dispersed along the San Andreas fault system, central California: International Geology Review, v. 55, p. 1575-1615, https://doi.org/10.1080/00206814.2013.825141.

Hart, 1977, K-Feldspar in Upper Mesozoic Sandstone Units near Atascadero, Santa Lucia Range, San Luis Obispo County, California: California Division of Mines and Geology Special Report 128, 21 p.

Herzig, C.T., and Kimbrough, D.L., 2014, Santiago Peak volcanics: Early Cretaceous arc volcanism of the western Peninsular Ranges batholith, southern California, in Morton, D.M., and Miller, F.K., eds., Peninsular Ranges Batholith, Baja California and Southern California: Geological Society of America Memoir 211, p. 345-363, https://doi.org/10.1130/2014.1211(09).

Hessler, A., and Fildani, A., 2015, Andean forearc dynamics, as recorded by detrital zircon from the Eocene Talara Basin, northwest Peru: Journal of Sedimentary Research, v. 85, p. 646-659, https://doi.org/10.2110/ jsr.2015.45.

Hill, M.L., and Dibblee, T.W., 1953, San Andreas, Big Pine, and Garlock faults, California-A study of the character, history and tectonic significance of their displacements: Geological Society of America Bulletin, v. 64, p. 443-458, https://doi.org/10.1130/0016-7606(1953)64[443:SAGABP] 2.0.CO;2.

Hopson, C.A., Mattinson, J.M., and Pessagno, E.A.J., 1981, Coast Range ophiolite, western California, in Ernst, W.G., ed., The Geotectonic Devel- opment of California, Rubey Volume I: Englewood Cliffs, New Jersey, Prentice-Hall, p. 419-510.

Hopson, C.A., Mattinson, J.M., Pessagno, E.A., and Luyendyk, B.P., 2008, California Coast Range ophiolite: Composite Middle and Late Jurassic oceanic lithosphere, in Wright, J.E., and Shervais, J.W., eds., Ophiolites, Arcs, and Batholiths: A Tribute to Cliff Hopson: Geological Society of America Special Paper 438, p. 1-101, https://doi.org/10.1130/2008.2438(01).

Ingersoll, R.V., 1982, Initiation and evolution of the Great Valley forearc basin of northern and central California, U.S.A., in Leggett, J.K., ed., TrenchForearc Geology: Sedimentation and Tectonics on Modern and Active Plate Margins: Geological Society, London, Special Publication 10, p. 459-467, https://doi.org/10.1144/GSL.SP.1982.010.01.31.

Ingersoll, R.V., 1983, Petrofacies and provenance of late Mesozoic forearc basin, northern and central California: American Association of Petroleum Geologists Bulletin, v. 67, p. 1125-1142.

Jacobson, C.E., Grove, M., Pedrick, J.N., Barth, A.P., Marsaglia, K.M., Gehrels, G., and Nourse, J.A., 2011, Late Cretaceous-early Cenozoic tectonic evolution of the southern California margin inferred from provenance of trench and forearc sediments: Geological Society of America Bulletin, v. 123, p. 485-506, https://doi.org/10.1130/B30238.1.

Jacobson, C.E., Hourigan, J.K., Haxel, G.B., and Grove, M., 2017, Extreme latest Cretaceous-Paleogene low-angle subduction: Zircon ages from Orocopia Schist at Cemetery Ridge, southwestern Arizona, USA: Geology, v. 45, p. 951-954, https://doi.org/10.1130/G39278.1.

Jiang, H., and Lee, C.-T.A., 2017, Coupled magmatism-erosion in continental arcs: Reconstructing the history of the Cretaceous Peninsular Ranges batholith, southern California through detrital hornblende barometry in forearc sediments: Earth and Planetary Science Letters, v. 472, p. 69-81, https://doi.org/10.1016/j.eps1.2017.05.009.

Johnson, S.E., Tate, M.C., and Fanning, C.M., 1999, New geologic mapping and SHRIMP U-Pb zircon data in the Peninsular Ranges batholith, Baja California, Mexico: Evidence for a suture?: Geology, v. 27, p. 743-746, https://doi .org/10.1130/0091-7613(1999)027<0743:NGMASU>2.3.CO;2.

Johnston, S.M., and Kylander-Clark, A., 2016, Rapid ophiolite exhumation and arc thickening in the southern California Late Cretaceous convergent margin as defined by Nacimiento block forearc detrital zircon geochronology and geochemistry: Geological Society of America Abstracts with Programs, v. 48, no. 4, paper 18-5, https://doi.org/10.1130/abs/2016CD-274291.

Kelemen, P.B., 1995, Genesis of high Mg\# andesite and the continental crust: Contributions to Mineralogy and Petrology, v. 120, p. 1-19, https://doi .org/10.1007/BF00311004.

Keppie, J.D., Currie, C.A., and Warren, C., 2009, Subduction erosion modes: Comparing finite element numerical models with the geological record: Earth and Planetary Science Letters, v. 287, p. 241-254, https://doi .org/10.1016/j.eps1.2009.08.009.

Kidder, S., Ducea, M., Gehrels, G., Patchett, P.J., and Vervoort, J.D., 2003, Tectonics and magmatic development of the Salinian Coast Ridge belt, California: Tectonics, v. 22, 1058, https://doi.org/10.1029/2002TC001409.

Kimbrough, D.L., Smith, D.P., Mahoney, B.J., Moore, T.E., Grove, M., Gastil, R.G., and Ortega-Rivera, A., 2001, Forearc-basin sedimentary response to rapid Late Cretaceous batholith emplacement in the Peninsular Ranges of southern and Baja California: Geology, v. 29, p. 491-494, https://doi .org/10.1130/0091-7613(2001)029<0491:FBSRTR>2.0.CO;2.

Kimbrough, D.L., Abbott, P.L., Balch, D.C., Bartling, S.H., Grove, M., and Mahoney, J.B., 2014, Upper Jurassic Peñasquitos Formation-Forearc basin western wall rock of the Peninsular Ranges batholith, in Morton, D.M., and Miller, F.K., eds., Peninsular Ranges Batholith, Baja California and Southern California: Geological Society of America Memoir 211, p. 625-643, https:// doi.org/10.1130/2014.1211(19)

Kistler, R., and Peterman, Z.E., 1978, Reconstruction of Crustal Blocks of California on the Basis of Initial Strontium Isotopic Compositions of Mesozoic Granitic Rocks: U.S. Geological Survey Professional Paper 1071, 17 p.

Kortyna, C., Donaghy, E., Trop, J., and Idleman, B., 2013, Integrated provenance record of a forearc basin modified by slab-window magmatism: Detrital-zircon geochronology and sandstone compositions of the Paleogene Arkose Ridge Formation, south-central Alaska: Basin Research, v. 25 , p. $1-25$.

Kylander-Clark, A.R.C., Hacker, B., and Cottle, J., 2013, Laser-ablation splitstream ICP petrochronology: Chemical Geology, v. 345, p. 99-112, https://doi.org/10.1016/j.chemgeo.2013.02.019.

Lackey, J.S., Cecil, M.R., Windham, C.J., Frazer, R.E., Bindeman, H.N., and Gehrels, G.E., 2012, Fine Gold intrusive suite: The roles of basement 
terranes and magma source development in the Early Cretaceous Sierra Nevada batholith: Geosphere, v. 8, p. 292-313, https://doi.org/10.1130/ GES00745.1.

LaMaskin, T.A., Vervoort, J.D., Dorsey, R.J., and Wright, J.E., 2011, Early Mesozoic paleogeography and tectonic evolution of the western United States: Insights from detrital zircon U-Pb geochronology, Blue Mountains Province, northeastern Oregon: Geological Society of America Bulletin, v. 123, p. 1939-1965, https://doi.org/10.1130/B30260.1.

Lee, C.-T.A., Thurner, S., Paterson, S., and Cao, W., 2015, The rise and fall of continental arcs: Interplays between magmatism, uplift, weathering, and climate: Earth and Planetary Science Letters, v. 425, p. 105-119, https:// doi.org/10.1016/j.eps1.2015.05.045.

Linn, A.M., DePaolo, D.J., and Ingersoll, R.V., 1992, Nd-Sr isotopic, geochemical, and petrographic stratigraphy and paleotectonic analysis: Mesozoic Great Valley forearc sedimentary rocks of California: Geological Society of America Bulletin, v. 104, p. 1264-1279, https://doi.org/10.1130/0016 -7606(1992) 104<1264:NSIGAP>2.3.CO;2.

Liu, L., Gurnis, M., Seton, M., Saleeby, J., Muller, R.D., and Jackson, J.M., 2010, The role of oceanic plateau subduction in the Laramide orogeny: Nature Geoscience, v. 3, p. 353-357, https://doi.org/10.1038/ ngeo829.

Ludwig, K., 2003, User's Manual for Isoplot 3.00: A Geochronological Toolkit for Microsoft Excel: Berkeley Geochronology Center Special Publication 4, $72 \mathrm{p}$.

Martin, M.W., and Clemens-Knott, D., 2015, Detrital-zircon record of the early Mesozoic southwestern Sierra Nevada arc preserved in Lower Cretaceous intra-arc and forearc deposits of central California, USA, in Anderson, T.H., Didenko, A.N., Johnon, C.L., Khanchuk, A.I., and MacDonald, J.H., Jr., eds., Late Jurassic Margin of Laurasia-A Record of Faulting Accommodating Plate Rotation: Geological Society of America Special Paper 513, p. 269-284, https://doi.org/10.1130/2015.2513(06).

Mattinson, J.M., 1990, Petrogenesis and evolution of the Salinian magmatic arc, in Anderson, J.L., ed., The Nature and Origin of Cordilleran Magmatism: Geological Society of America Memoir 174, p. 237-250, https://doi .org/10.1130/MEM174-p237.

McLean, H., Howell, D.G., and Vedder, J.G., 1977, An unusual Upper Cretaceous conglomerate in the central San Rafael Mountains, Santa Barbara County, California, in Howell, D.G., Vedder, J.G., and McDougall, K.A. eds., Cretaceous Geology of the California Coast Ranges, West of the San Andreas Fault: Los Angeles, California, Pacific Section, Society of Economic Paleontologists and Mineralogists (SEPM), Pacific Coast Paleogeography Field Guide 2, p. 79-84.

McWilliams, M.O., and Howell, D.G., 1982, Exotic terranes of western California: Nature, v. 297, p. 215-217, https://doi.org/10.1038/297215a0.

Miller, J.S., Glazner, A.F., Walker, J.D., and Martin, M.W., 1995, Geochronologic and isotopic evidence for Triassic-Jurassic emplacement of the eugeoclinal allochthon in the Mojave Desert region, California: Geological Society of America Bulletin, v. 107, p. 1441-1457.

Mistretta, T., Estrada, J., Clemens-Knott, D., Barth, A.P., and Wooden, J.L., 2016, Using zircon trace element signatures to evaluate the nature of Middle to Late Jurassic magmatism within the Sierra Nevada arc: Geological Society of America Abstracts with Programs, v. 48, no. 7, paper 267-3, https://doi.org/10.1130/abs/2016AM-281763.

Moxon, I.W., 1988, Sequence stratigraphy of the Great Valley Basin in the context of convergent margin tectonics, in Graham, S.A., ed., Studies of the Geology of the San Joaquin Basin: Los Angeles, California, Pacific Section, Society of Economic Paleontologists and Mineralogists (SEPM), Book 60, p. 3-28.

Moxon, I.W., and Graham, S.A., 1987, History and controls of subsidence in the Late Cretaceous-Tertiary Great Valley forearc basin, California: Geology, v. 15, p. 626-629, https://doi.org/10.1130/0091-7613(1987)15<626 :HACOSI $>2.0 . \mathrm{CO} ; 2$

Nelson, A.S., 1979, Upper Cretaceous Depositional Environments and Provenance Indicators in the Central San Rafael Mountains, Santa Barbara County, California [M.A. thesis]: Santa Barbara, California, University of California, $153 \mathrm{p}$

Noda, A., 2016, Forearc basins: Types, geometries, and relationships to subduction zone dynamics: Geological Society of America Bulletin, v. 128 , p. 879-895, https://doi.org/10.1130/B31345.1.

Onderdonk, N.W., 2005, Structures that accommodated differential vertical axis rotation of the western Transverse Ranges, California: Tectonics, v. 24, TC4018, https://doi.org/10.1029/2004TC001769.
Ortega-Rivera, A., 2003, Geochronological constraints on the tectonic history of the Peninsular Ranges batholith of Alta and Baja California: Tectonic implications for western Mexico, in Johnson, S.E., Paterson, S.R., Fletcher, J.M., Girty, G.H., Kimbrough, D.L., and Martín-Barajas, A., eds., Tectonic Evolution of Northwestern Mexico and the Southwestern USA: Geological Society of America Special Paper 374, p. 297-335, https://doi.org/10.1130/0-8137-2374-4.297.

Page, B., 1970, Sur-Nacimiento fault zone of California: Continental margin tectonics: Geological Society of America Bulletin, v. 81, p. 667-690, https://doi.org/10.1130/0016-7606(1970)81[667:SFZOCC]2.0.CO;2.

Page, B., 1972, Oceanic crust and mantle fragment in subduction complex near San Luis Obispo, California: Geological Society of America Bulletin, v. 83, p. 957-972, https://doi.org/10.1130/0016-7606(1972)83[957 :OCAMFI]2.0.CO;2.

Page, B., 1982, Migration of Salinian composite block, California, and disappearance of fragments: American Journal of Science, v. 282, p. 1694 1734, https://doi.org/10.2475/ajs.282.10.1694.

Paterson, S.R., and Ducea, M.N., 2015, Arc magmatic tempos: Gathering the evidence: Elements, v. 11, p. 91-98, https://doi.org/10.2113/ gselements.11.2.91.

Paton, C., Woodhead, J., Hellstrom, J., Hergt, J., Greig, A., and Maas, R., 2010, Improved laser ablation U-Pb zircon geochronology through robust down-hole fractionation correction: Geochemistry Geophysics Geosystems, v. 11, QOAA06, https://doi.org/10.1029/2009GC002618.

Platt, J.P., 1986, Dynamics of orogenic wedges and the uplift of highpressure metamorphic rocks: Geological Society of America Bulletin, v. 97, p. 1037-1053, https://doi.org/10.1130/0016-7606(1986)97<1037 :DOOWAT $>2.0 . \mathrm{CO} ; 2$

Premo, W.R., and Morton, D.M., 2014, SHRIMP-RG U-Pb ages of provenance and metamorphism from detrital zircon populations and $\mathrm{Pb}-\mathrm{Sr}-\mathrm{Nd}$ signatures of prebatholithic metasedimentary rocks at Searl Ridge, northern Peninsular Ranges batholith, southern California: Implications for their age, origin, and tectonic setting, in Morton, D.M., and Miller, F.K., eds., Peninsular Ranges Batholith, Baja California and Southern California: Geological Society of America Memoir 211, p. 449-498, https://doi .org/10.1130/2014.1211(14).

Premo, W.R., Morton, D.M., Wooden, J.L., and Fanning, C.M., 2014, U-Pb zircon geochronology of plutonism in the northern Peninsular Ranges batholith, southern California: Implications for the Late Cretaceous tectonic evolution of southern California, in Morton, D.M., and Miller, F.K., eds., Peninsular Ranges Batholith, Baja California and Southern California: Geological Society of America Memoir 211, p. 145-180, https://doi .org/10.1130/2014.1211(04).

Ross, D.C., 1978, The Salinian block-A Mesozoic granitic orphan in the California Coast Ranges, in Howell, D.G., and McDougall, K.A., eds., Mesozoic Paleogeography of the Western United States: Los Angeles, California, Pacific Section, Society of Economic Paleontologists and Mineralogists (SEPM), Pacific Coast Paleogeography Symposium 2, p. 509-522.

Rudnick, R.L., 1995, Making continental crust: Nature, v. 378, p. 571-578, https://doi.org/10.1038/378571a0

Saleeby, J.B., 2003, Segmentation of the Laramide slab-Evidence from the southern Sierra Nevada region: Geological Society of America Bulletin, v. 115, p. 655-668, https://doi.org/10.1130/0016-7606(2003) $115<0655$ :SOTLSF $>2.0 . \mathrm{CO} ; 2$.

Saleeby, J.B., 2007, Western extent of the Sierra Nevada batholith in the Great Valley basement: Abstract T31E-02 presented at 2007 Fall Meeting, American Geophysical Union, San Francisco, California, 10-14 December.

Saleeby, J.B., Geary, E.E., Paterson, S.R., and Tobisch, O.T., 1989a, Isotopic systematics of $\mathrm{Pb} / \mathrm{U}$ (zircon) and ${ }^{40} \mathrm{Ar} /{ }^{39} \mathrm{Ar}$ (biotite-hornblende) from rocks of the central Foothills terrane, Sierra Nevada, California: Geological Society of America Bulletin, v. 101, p. 1481-1492, https://doi .org/10.1130/0016-7606(1989)101<1481:ISOPUZ>2.3.CO;2.

Saleeby, J.B., Shaw, H.F., Niemeyer, S., Moores, E.M., and Edelman, S.H., $1989 b, \mathrm{U} / \mathrm{Pb}, \mathrm{Sm} / \mathrm{Nd}$, and $\mathrm{Rb} / \mathrm{Sr}$ geochronological and isotopic study of northern Sierra Nevada ophiolitic assemblage, California: Contributions to Mineralogy and Petrology, v. 102, p. 205-220, https://doi.org/10.1007/ BF00375341.

Schoenborn, W.A., Fedo, C.M., and Farmer, G.L., 2012, Provenance of the Neoproterozoic Johnnie Formation and Stirling Quartzite, southeastern California, determined by detrital zircon geochronology and $\mathrm{Nd}$ isotope geochemistry: Precambrian Research, v. 206-207, p. 182-199, https:// doi.org/10.1016/j.precamres.2012.02.017. 
Scholl, D.W., and von Huene, R., 2007, Crustal recycling at modern subduction zones applied to the past: Issues of growth and preservation of continental basement crust, mantle geochemistry, and supercontinent reconstruct ion, in Hatcher, R.D., Jr., Carlson, M.P., McBride, J.H., and Martínez Catalán, J.R., eds., 4-D Framework of Continental Crust: Geological Society of America Memoir 200, p. 9-32, https://doi.org/10.1130/2007.1200(02).

Scholl, D.W., von Huene, R., Vallier, T.L., and Howell, D.G., 1980, Sedimentary masses and concepts about tectonic processes at underthrust ocean margins: Geology, v. 8, p. 564-568, https://doi.org/10.1130/0091 $-7613(1980) 8<564:$ SMACAT $>2.0$. CO 2 .

Seiders, V.M., 1982, Geologic Map of an Area near York Mountain, San Luis Obispo County, California: U.S. Geological Survey Miscellaneous Investigations Series Map I-369, scale 1:24,000.

Seiders, V.M., 1983, Correlation and provenance of Upper Mesozoic chertrich conglomerate of California: Geological Society of America Bulletin, v. 94, p. 875-888, https://doi.org/10.1130/0016-7606(1983)94<875 $:$ CAPOUM $>2.0 . \mathrm{CO} ; 2$.

Seiders, V.M., and Blome, C.D., 1988, Implications of Upper Mesozoic conglomerate for suspect terrane in western California and adjacent areas: Geological Society of America Bulletin, v. 100, p. 374-391, https://doi .org/10.1130/0016-7606(1988)100<0374:IOUMCF>2.3.CO;2.

Sharman, G.R., Graham, S.A., Grove, M., and Hourigan, J.K., 2013, A reappraisal of the early slip history of the San Andreas fault, central California, USA: Geology, v. 41, p. 727-730, https://doi.org/10.1130/G34214.1.

Sharman, G.R., Graham, S.A., Grove, M., Kimbrough, D.L., and Wright, J.E., 2015, Detrital zircon provenance of the Late Cretaceous-Eocene California forearc: Influence of Laramide low-angle subduction on sediment dispersal and paleogeography: Geological Society of America Bulletin, v. 127, p. 38-60, https://doi.org/10.1130/B31065.1.

Shaw, S.E., Todd, V.R., and Grove, M., 2003, Jurassic peraluminous gneissic granites in axial zone of Peninsular Ranges, southern California, in Johnson, S.E., Paterson, S.R., Fletcher, J.M., Girty, G.H., and Kimbrough, D.L., eds., Tectonic Evolution of Northwestern Mexico and the Southwestern USA: Geological Society of America Special Paper 374, p. 157183, https://doi.org/10.1130/0-8137-2374-4.157.

Silver, L.T., Taylor, H.P., and Chappel, B.W., 1979, Some petrological, geochemical and geochronological observations of the Peninsular Ranges batholith near the international border of the USA and Mexico, in Abbott, P.L., and Todd, V.R., eds., Mesozoic Crystalline Rocks: San Diego, California, San Diego State University, p. 189-196.

Spencer, J.E., Richard, S.M., Gehrels, G.E., Gleason, J.D., and Dickinson, W.R., 2011, Age and tectonic setting of the Mesozoic McCoy Mountains Formation in western Arizona, USA: Geological Society of America Bulletin, v. 123, p. 1258-1274, https://doi.org/10.1130/B30206.1.

Surpless, K.D., 2015, Geochemistry of the Great Valley Group: An integrated provenance record: International Geology Review, v. 57, p. 747-766, https://doi.org/10.1080/00206814.2014.923347.
Surpless, K.D., Graham, S.A., Covault, J.A., and Wooden, J.L., 2006, Does the Great Valley Group contain Jurassic strata? Reevaluation of the age and early evolution of a classic forearc basin: Geology, v. 34, p. 21-24, https:// doi.org/10.1130/G21940.1.

Ukar, E., Cloos, M., and Vasconcelos, P., 2012, First ${ }^{40} \mathrm{Ar} /{ }^{39} \mathrm{Ar}$ ages from low-T mafic blueschist blocks in a Franciscan mélange near San Simeon: Implications for initiation of subduction: Journal of Geology, v. 120, p. 543556, https://doi.org/10.1086/666745.

Vedder, J.G., Gower, H.D., Clifton, H.E., and Durham, D.L., 1967, Reconnaissance Geologic Map of the Central San Rafael Mountains and Vicinity, Santa Barbara County, California: U.S. Geological Survey Miscellaneous Investigations Series Map I-487, scale 1:48,000.

Vedder, J.G., Howell, D.G., and McLean, H., 1983, Stratigraphy, sedimentation, and tectonic accretion of exotic terranes, southern Coast Ranges, California, in Watkins, J.S., and Drakes, C.L., eds., Studies in Continental Margin Geology: American Association of Petroleum Geologists Memoir 34, p. 471-496.

Wakabayashi, J., 2015, Anatomy of a subduction complex: Architecture of the Franciscan complex, California, at multiple length and time scales: International Geology Review, v. 57, p. 669-746, https://doi.org/10.1080/ 00206814.2014.998728.

Wakabayashi, J., and Dumitru, T.A., 2007, ${ }^{40} \mathrm{Ar} /{ }^{39} \mathrm{Ar}$ ages from coherent, highpressure metamorphic rocks of the Franciscan complex, California: Revisiting the timing of metamorphism of the world's type subduction complex: International Geology Review, v. 49, p. 873-906, https://do .org/10.2747/0020-6814.49.10.873.

Wiedenbeck, M., Alle, P., Corfu, F., Griffin, W.L., Meier, M., Oberli, F., Von Quadt, A., Roddick, C., and Spiegel, W., 1995, Three natural zircon standards for U-Th- $\mathrm{Pb}$, Lu-Hf, trace element, and REE analyses: Geostandards Newsletter, v. 19, p. 1-23, https://doi.org/10.1111/j.1751-908X 1995.tb00147.x.

Williams, T.A., and Graham, S.A., 2013, Controls on forearc basin architecture from seismic and sequence stratigraphy of the Upper Cretaceous Great Valley Group, central Sacramento Basin, California: International Geology Review, v. 55, p. 2030-2059, https://doi.org/10.1080/00206814 2013.817520.

Wright, J.E., and Wyld, S., 2007, Alternative tectonic model for Late Jurassic through Early Cretaceous evolution of the Great Valley Group, California, in Cloos, M., Carlson, W., Gilbert, M.C., Liou, J.G., and Sorensen, S.S., eds., Convergent Margin Terranes and Associated Regions: A Tribute to W.G. Ernst: Geological Society of America Special Paper 419, p. 81-95, https://doi.org/10.1130/2007.2419(04).

Manuscript Accepted by the Society 5 February 2018

Manuscript Published Online 15 October 2018 